Article

\title{
Simulation and Optimization of the CWPO Process by Combination of Aspen Plus and 6-Factor Doehlert Matrix: Towards Autothermal Operation
}

\author{
Jose L. Diaz de Tuesta ${ }^{1}\left(\mathbb{D}\right.$, Asunción Quintanilla ${ }^{2, *}$, Daniel Moreno ${ }^{2}$, Víctor R. Ferro ${ }^{2} \mathbb{C}$ and \\ Jose A. Casas ${ }^{2}$ \\ 1 Mountain Research Center (CIMO), Polytechnic Institute of Bragança, Campus de Santa Apolónia, \\ 5300253 Bragança, Portugal; jl.diazdetuesta@ipb.pt \\ 2 Chemical Engineering Department, Faculty of Science, Autonomous University of Madrid, Cantoblanco, \\ Ctra. de Colmenar km 15, 28049 Madrid, Spain; daniel.moreno@uam.es (D.M.); victor.ferro@uam.es (V.R.F.); \\ jose.casas@uam.es (J.A.C.) \\ * Correspondence: asun.quintanilla@uam.es; Tel.: +34-91-497-34-54
}

Received: 1 May 2020; Accepted: 13 May 2020; Published: 15 May 2020

\begin{abstract}
This work aims to present an industrial perspective on Catalytic Wet Peroxide Oxidation (CWPO) technology. Herein, process simulation and experimental design have been coupled to study the optimal process conditions to ensure high-performance oxidation, minimum $\mathrm{H}_{2} \mathrm{O}_{2}$ consumption and maximum energetic efficiency in an industrial scale CWPO unit. The CWPO of phenol in the presence of carbon black catalysts was studied as a model process in the Aspen Plus ${ }^{\circledR}$ v11 simulator. The kinetic model implemented, based on 30 kinetic equations with 11 organic compounds and $\mathrm{H}_{2} \mathrm{O}_{2}$ involvement, was valid to describe the complex reaction network and to reproduce the experimental results. The computer experiments were designed on a six-factor Doehlert Matrix in order to describe the influence of the operating conditions (i.e., the different process temperatures, inlet chemical oxygen demands, doses of $\mathrm{H}_{2} \mathrm{O}_{2}$ and space time) on each selected output response (conversion, efficiency of $\mathrm{H}_{2} \mathrm{O}_{2}$ consumption and energetic efficiency) by a quadratic model. The optimization of the WPO performance by a multi-criteria function highlighted the inlet chemical oxygen demand as the most influential operating condition. It needed to have values between 9.5 and $24 \mathrm{~g} \mathrm{~L}^{-1}$ for autothermal operation to be sustained under mild operating conditions (reaction temperature: 93-130 ${ }^{\circ} \mathrm{C}$ and pressure: $1-4 \mathrm{~atm}$ ) and with a stoichiometric dose of $\mathrm{H}_{2} \mathrm{O}_{2}$.
\end{abstract}

Keywords: catalytic wet peroxide oxidation; carbon catalyst; ASPEN plus; simulation and optimization; design of experiments; energetic efficiency; heat integration; surface response methodology

\section{Introduction}

Advanced oxidation processes (AOPs) are technologies that involve the generation of hydroxyl radicals in sufficient quantities to mineralize recalcitrant pollutants to carbon dioxide, water and inorganics or, at least, to transform them into harmless products. Wastewater with relative low chemical oxygen demand ( $\mathrm{COD}<5 \mathrm{~g} \mathrm{~L}^{-1}$ ) is suitably treated under near ambient conditions by different types of oxidant i.e., $\mathrm{H}_{2} \mathrm{O}_{2}, \mathrm{O}_{2}$ and $\mathrm{O}_{3}$. In addition, these processes can be photo and electro assisted. The treatment of highly loaded wastewater $\left(\mathrm{COD}>20 \mathrm{~g} \mathrm{~L}^{-1}\right)$ requires the employment of thermal technologies, namely wet air oxidation (WAO) or catalytic wet air oxidation (CWAO), that operate under high temperatures $(\mathrm{T})$ and pressures $(\mathrm{P}), 130-300{ }^{\circ} \mathrm{C}$ and 5-200 atm, respectively [1]. The selection of each technology depends on many factors, such as the technical effectiveness using real streams, the manageability and applicability to the specific operations and the cost, among others [2-4]. 
For medium-high concentrations of COD $\left(5-20 \mathrm{~g} \mathrm{~L}^{-1}\right)$, the combination of processes is proposed to provide technical solutions for each specific wastewater, but it entails a consequent increase in the cost of the treatment.

Alternatively, catalytic wet peroxide oxidation (CWPO) is a technology, developed at the end of the nineteen nineties [5], that has also shown great potential for the removal of recalcitrant organic compounds contained at medium-high concentrations of COD [4,6-9]. This process requires a solid catalyst with redox properties to decompose $\mathrm{H}_{2} \mathrm{O}_{2}$ into hydroxyl and hydroperoxyl radicals under mild conditions $\left(\mathrm{T}=50-100^{\circ} \mathrm{C}\right.$ and $\left.\mathrm{P}=1-5 \mathrm{~atm}\right)$. In comparison to $\mathrm{CWAO}$, the $\mathrm{CWPO}$ units require less capital injection, because the operating conditions make it unnecessary to use special reactors and materials, though it generates higher running costs due to the consumption of $\mathrm{H}_{2} \mathrm{O}_{2}$ instead of $\mathrm{O}_{2}$ [6]. Additionally, CWPO units are intrinsically safer, the formation of foams and odors is much lower than for CWAO, it could be a technology movable from site to site and it does not require highly specialized personal [4]. These reasons have incentivized the research and development of this technology.

CWPO research studies published in the past 20 years have conscientiously focused on searching for stable and efficient solid catalysts such as iron or/and carbon based catalysts [10-13] and the proposal of kinetic models to envisage a reaction mechanism. The conformation of catalysts in suitable morphologies (spheres, pellets or trefoils) has allowed operation in continuous mode in fixed bed reactors [14-19], and hence, the study of the durability of the catalysts exposed to long-term operation and the influence of the operating conditions on the oxidation performance. Furthermore, CWPO was studied in a pilot scale process [20]. The recent development of structured catalysts/reactors using monolith [21-23] or structured cellular foams [24,25] has circumvented the barrier to scaling up. Besides, a variety of agro-food effluents i.e., from coffee [26], olive oil mills [27-29] and wineries [30], and industrial effluents, i.e., from textile [31], pharmaceutical [32], cosmetic [33] and chemical production [34-36], have been suitable treated by this technology. More recently, it has also been demonstrated to be a feasible technique to reduce the impact of residual contaminants, such as persistent endocrine-disrupting chemicals [36], present in very low concentrations in urban wastewater, or antibiotics and other pharmaceuticals in sanitary wastewater [37-39].

Despite the potential offered by CWPO, which can be exploited to treat industrial and domestic wastewater before or after a biological treatment within a wide range of pollutant loads $[4,36]$ with a simple installation, since conventional atmospheric pressure reactors may be used, there are no commercial CWPO processes with solid catalysts. This work serves to help translate CWPO research into an industrial reality.

The novelty of this work lies in the analysis of the industrial operation of the CWPO technology by using a simulator, ASPEN Plus ${ }^{\circledR} \mathrm{v} 11$, and then carrying out a multi-criteria optimization of the oxidation process in order to consider the application of the CWPO in a reliable and economical manner. Particular emphasis is put on the necessity of maintaining an autothermic or energetically self-sustaining operation; therefore, the pollutant load of the wastewater and the reaction temperature are operational conditions that have been carefully considered. In addition, the $\mathrm{H}_{2} \mathrm{O}_{2}$ dose and consumption must be also taken into account for the economy of the process.

Our previous experience of using CWPO for phenolic wastewater with carbon black catalysts [40], with a comprehensive kinetic model that describes the oxidation and mineralization of 11 organic compounds (including phenol, oxidized intermediates and by-products) and the $\mathrm{H}_{2} \mathrm{O}_{2}$ consumption, has encouraged us to consider it as a case study. The design of experiments, by a six-factor Doehlert matrix, has been combined with simulation as an efficient way to minimize the number of simulation runs and to assemble all the significant operating variables in equations to facilitate the interpretation of the results [41-44]. The CWPO process optimization has also been addressed by considering the operating variables under the best oxidation performance (maximum pollutant abatement) in an economical manner (maximum efficiency of $\mathrm{H}_{2} \mathrm{O}_{2}$ consumption and heat released). 


\section{Computational Details}

\subsection{Process Simulation Flowsheet}

The simulation of the CWPO process was carried out with Aspen Plus ${ }^{\circledR}$ v11. A flow and temperature diagram of the base case configuration is depicted in Figure 1. As can be seen, the wastewater, which contains the target pollutant (phenol in this case), enters the process (S-01) and mixes with a flow of $\mathrm{H}_{2} \mathrm{O}_{2}$ (S-02). The resulting stream (S-03) at $\mathrm{T}_{\mathrm{S}-03}$ and a dose of $\mathrm{H}_{2} \mathrm{O}_{2}$ predefined with respect to the stoichiometric one for complete phenol mineralization are led to a heater (E-100) to increase the temperature to reaction conditions $\left(T_{R}\right)$. Then, the heated stream (S-04) is fed to the fixed-bed reactor (R-100), where the oxidation of phenol and its oxidized intermediates take place under isothermal conditions in the presence of a catalyst (carbon black, in this case). In the current process model, the reaction took place only in R-100. The CWPO reactor was modeled as an isothermal plug-flow reactor. The temperature of the liquid outlet stream of the reactor (S-05) was decreased in a cooler (E-101) to the temperature predefined for the process outlet stream (T-06). $\mathrm{T}_{\mathrm{S}-06}$ was always $5{ }^{\circ} \mathrm{C}$ above $\mathrm{T}_{\mathrm{S}-03}$ to maintain a minimum pinch point for the viability of the process heat exchanger network. The heat duty of the different unit operations was defined as $\mathrm{H}-01, \mathrm{H}-02$ and $\mathrm{H}-03$, for the heater (E-100), cooler (E-101) and fixed-bed reactor (R-100), respectively (Figure 1).

A)

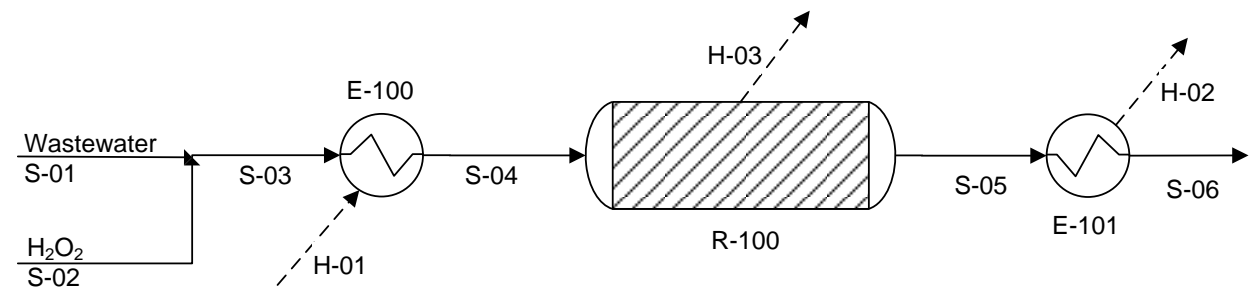

B)

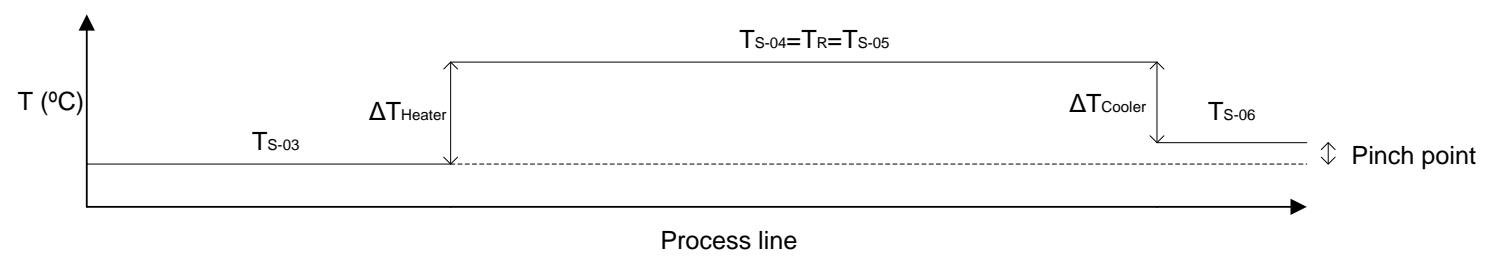

Figure 1. Flowsheet of the Catalytic Wet Peroxide Oxidation (CWPO) process implemented in the ASPEN Plus ${ }^{\circledR}$ v11 simulator (A) and the temperature line diagram of the process (B).

The mass flows of the streams and dimensions of the reactor and the heaters were arbitrary, since only non-dimensional variables are taken into account in this work (see Section "Variables definition"). In addition, the pressure drop in the pipes and equipment was considered negligible, and the operating pressure was fixed at 4 bar, the same as that used to obtain the kinetic equations [40].

\subsection{Reaction Pathway and Kinetic Model}

The kinetic model used to simulate the CWPO of phenol upon a carbon black catalyst was experimentally obtained in a batch-reactor in the absence of mass transfer limitation and according to the reaction pathway previously proposed [40]. Briefly, phenol is oxidized to aromatic intermediates-namely, resorcinol (RS), catechol (CTL), hydroquinone (HQ) and p-benzoquinone (BQ) — in parallel reactions, and these cyclic species are broken down into different carboxylic acids, namely, maleic (MAL), fumaric (FUM), malonic (MLO), oxalic (OXA), acetic (ACE) and formic (FORM) 
acid. This reaction pathway comprises a set of 30 elementary reactions (summarized in Table S1 of the Supplementary Material), with the following rate Equation:

$$
R_{i}=\frac{1}{C_{c a t}} \cdot \frac{d C_{i}}{d t}=k_{i} \cdot C_{i} \cdot C_{H_{2} \mathrm{O}_{2}}
$$

where $C_{c a t}, C_{i}$ and $C_{\mathrm{H}_{2} \mathrm{O}_{2}}$ refer to the concentrations of the catalyst, organic compound $i$ and $\mathrm{H}_{2} \mathrm{O}_{2}$, respectively, while $\mathrm{k}_{\mathrm{i}}$ is the rate constant.

The kinetic rate constant values were estimated from the fitted experimental data in the previous work of Diaz de Tuesta et al. [40]. The $\mathrm{H}_{2} \mathrm{O}_{2}$ consumption rate was calculated from the production rate of each organic compound and the stoichiometric coefficient of the corresponding Equation (Table S1 of the Supplementary Material).

\subsection{Components and Property Model Selection}

The components considered in the simulation were $\mathrm{H}_{2} \mathrm{O}_{2}, \mathrm{CO}_{2}, \mathrm{~N}_{2}, \mathrm{O}_{2}, \mathrm{H}_{2} \mathrm{O}$, phenol and the oxidized species mentioned above.

The UNIQUAC property model was selected to estimate the fluid properties in the process simulations. Most of the parameters were taken from the Aspen Property and NIST databases available in Aspen Plus. The unknown (water/organic compounds, $\mathrm{CO}_{2} / \mathrm{O}_{2}$ and $\mathrm{O}_{2} / \mathrm{N}_{2}$ ) binary interaction parameters were either estimated by the group contribution methods or fitted by the regression of experimental data using, respectively, the estimation and regression algorithms implemented in Aspen Plus. The experimental data of the corresponding vapor/gas-liquid equilibria were used to fit the unknown UNIQUAC binary parameters. They were retrieved from the literature [45-49] and the NIST database. The NIST database was accessed through the link implemented in Aspen Plus and supported by the NIST Thermo Data Engine. The binary interaction parameters used in this work are shown in Table S2 of the Supplementary Material. The gases considered in the simulations $\left(\mathrm{CO}_{2}, \mathrm{O}_{2}\right.$ and $\mathrm{N}_{2}$ ) were defined as Henry components. The corresponding binary gas/water parameters for the Henry equation were obtained from the Aspen Property database. The heats of formation of all the components involved in the chemical reactions were taken from the Aspen Property database.

\subsection{Variable Definition}

The simulation of the CWPO process was run to explore the influence of six operating variables on six selected responses. The operating variables of the process studied were:

$\mathrm{T}_{\mathrm{R}}$, the reaction temperature $\left({ }^{\circ} \mathrm{C}\right)$.

$\mathrm{T}_{\text {input }}$, the heater E-100 inlet temperature $\left({ }^{\circ} \mathrm{C}\right)$, equal to $\mathrm{T}_{\mathrm{S}-01}=\mathrm{T}_{\mathrm{S}-02}=\mathrm{T}_{\mathrm{S}-03}$ as shown in Figure 1.

$\mathrm{T}_{\text {output }}$, the cooler E-101 outlet temperature $\left({ }^{\circ} \mathrm{C}\right)$, equal to $\mathrm{T}_{\mathrm{S}-06}$ as shown in Figure 1.

$\mathrm{ThOD}_{\text {feed, }}$, the COD of the wastewater $\left(\mathrm{g} \cdot \mathrm{L}^{-1}\right)$. In this work, it is calculated from the concentration of phenol fed to the reactor then named as theoretical oxygen demand fed to the reactor.

$\mathrm{HP}_{\text {excess, }}$ the excess of $\mathrm{H}_{2} \mathrm{O}_{2}$ with respect to the stoichiometric dose.

$\tau$, the space time in $\mathrm{g}_{\text {cat }}$ mol $_{\text {phenol }}{ }^{-1} \mathrm{~h}^{-1}$, calculated as in Equation (2) by the ratio of the mass of the catalyst $(\mathrm{W})$ to the inlet phenol molar flow rate $(\mathrm{F})$.

$$
\tau=\frac{W\left(g_{\text {cat }}\right)}{F_{\text {phenol, inlet }}\left(\text { mol }_{\text {phenol }} \cdot h^{-1}\right)}
$$

The selected response variables were as follows:

$X_{j}$ is the conversion of phenol, $\mathrm{H}_{2} \mathrm{O}_{2}$, theoretical oxygen demand (ThOD) or total organic carbon (TOC). It is calculated according to Equation (3), in terms of molar flow (for phenol and $\mathrm{H}_{2} \mathrm{O}_{2}$ ) or mass flow (for ThOD and TOC):

$$
X_{j}(\%)=\frac{F_{j, \text { inlet }}-F_{j, \text { outlet }}}{F_{j, \text { inlet }}} \cdot 100
$$


The calculation of ThOD and TOC, $\mathrm{g} \mathrm{L}^{-1}$, for the inlet and outlet streams of the reactor is provided in Table $\mathrm{S} 3$ of the Supplementary Material.

$\eta_{\mathrm{H}_{2} \mathrm{O}_{2}}$ is the efficiency of the $\mathrm{H}_{2} \mathrm{O}_{2}$ consumption. It was calculated according to the amount of $\mathrm{H}_{2} \mathrm{O}_{2}$ necessary to oxidize 1 mol of carbon, as expressed in Equation (4) [50]:

$$
\eta_{\mathrm{H}_{2} \mathrm{O}_{2}}(\%)=\frac{F_{T O C, \text { inlet }}-F_{T O C, \text { outlet }}}{F_{\mathrm{H}_{2} \mathrm{O}_{2, \text { inlet }}}-F_{\mathrm{H}_{2} \mathrm{O}_{2, \text { outlet }}}} \cdot\left(\frac{2 \mathrm{~mol}_{\mathrm{H} 2 \mathrm{O} 2}}{1 \mathrm{~mol} \mathrm{TOC}}\right) \cdot 100
$$

$\eta_{E}$ is the energetic efficiency. It is calculated as the ratio of the process of "heat release" (through the cooler $\mathrm{H}-02$ and reactor $\mathrm{H}-03$ ) to "heat needed" (through the heater H-01). For that, a heat loss of $3 \%$ has been considered for heat exchangers and $10 \%$ for the chemical reactor [51]:

$$
\eta_{E}(\%)=\frac{|H-02| \cdot 0.97+|H-03| \cdot 0.90}{|H-01| \cdot 0.97} \cdot 100
$$

Energetic efficiency values above $100 \%$ imply that the heat released by the CWPO reaction can be recovered to preheat the incoming feed stream. This means that the CWPO process is energetically self-sufficient or can be run under autothermal operation.

\subsection{Design of Experiments}

The study of the influence of the selected operating variables $\mathrm{T}_{\mathrm{R}}, \mathrm{T}_{\text {input }}, \mathrm{T}_{\text {output }}, \mathrm{ThOD}_{\text {feed }}, \mathrm{HP}_{\text {excess }}$ and $\tau$ on the responses $X_{\text {phenol }}, X_{\text {ThOD }}, X_{\mathrm{H}_{2} \mathrm{O}_{2}}, X_{\mathrm{TOC}}, \eta_{\mathrm{H}_{2} \mathrm{O}_{2}}$ and $\eta_{\mathrm{E}}$ in the CWPO process, with the minimum number of simulation runs, was carried out based on a six-factor Doehlert Matrix.

The resulting numerical experiments, or cases, to simulate by Aspen Plus numbered 43. Table 1 shows these experiments with the real and code values for each operating variable. The different ranges of interest to assign the real values were the following: $\mathrm{T}_{\mathrm{R}}$ from 50 to $130^{\circ} \mathrm{C}$, taking into account that the oxidation rate is almost negligible below $50{ }^{\circ} \mathrm{C}$ [ 40 ]; $\mathrm{ThOD}_{\text {feed }}$ from 2.38 to $23.8 \mathrm{~g} \cdot \mathrm{L}^{-1}$, corresponding to an inlet phenol concentration equal to $1-10 \mathrm{~g} \mathrm{~L}^{-1}$, an appropriate pollutant load for the CWPO processes [8,36]; $\mathrm{T}_{\text {output }}$ from 30 to $60^{\circ} \mathrm{C}$, taking into account the values of the pitch point above 5 ${ }^{\circ} \mathrm{C}$ - the minimum value is $8.7^{\circ} \mathrm{C}$ in Case 35 and the maximum, $41.2^{\circ} \mathrm{C}$ in Case 41 . Additionally, the Doehlert Matrix allows the simulation of this range of values without temperature crossing, thus avoiding inconsistent behavior scenarios such as $\mathrm{T}_{\text {output }}$ values above $\mathrm{T}_{\mathrm{R}}$. The $\mathrm{HP}_{\text {excess }}$ varied from $50 \%$ to $150 \%$ respect to the stoichiometric dose. The $\tau$ was between 94 and $235 \mathrm{~g}$ cat $\cdot h \cdot \mathrm{mol}_{\text {phenol }}{ }^{-1}$, in the range of values reported for flow reactors [15-22]. $\mathrm{T}_{\text {input }}$ ranged from 15 to $25^{\circ} \mathrm{C}$, which reflects the worst scenario.

The function selected to describe the dependence between each response and the operating variables was a second-order polynomial equation:

$$
y=\beta_{0}+\sum_{i=1}^{n} \beta_{i} \cdot x_{i}+\sum_{i=1}^{n} \beta_{i i} \cdot x_{i}^{2}+\sum_{i<j=1}^{n} \beta_{i j} \cdot x_{i} \cdot x_{j}+\varepsilon
$$

where $y$ represents the predicted response; $x_{i}$ and $x_{j}$, the codes of the operating variables (provided in Table 1 as $\mathrm{x}_{1}=\mathrm{T}_{\mathrm{R}}, \mathrm{x}_{2}=\mathrm{ThOD}_{\text {feed }}, \mathrm{x}_{3}=\mathrm{T}_{\text {output }}, \mathrm{x}_{4}=\mathrm{HP}_{\text {excess }}, \mathrm{x}_{5}=\tau$ and $\mathrm{x}_{6}=\mathrm{T}_{\text {input }}$ ); and $\beta$, the regression coefficients where $\beta_{0}$ is the intercept, $\beta_{\mathrm{i}}$ is the coefficient for linear effects, $\beta_{\mathrm{ii}}$ is that for quadratic effects and $\beta_{\mathrm{ij}}$ is that for two-factor interaction effects.

The Solver tool in Microsoft ${ }^{\circledR}$ Excel, which employs the Generalized Reduced Gradient algorithm, was used to estimate the coefficients by multiple non-linear regression. The analysis of variance (ANOVA) was used to evaluate both the coefficients' statistical significance and the fitting of the function. The objective functions were maximized or minimized, as appropriate, using as restrictions the minimum and maximum values of the operating variables provided in Table 1 . The optimization was run under several interactions and with more than 100 starting points (arbitrarily chosen). 
Table 1. Design of experiments based on the six-factor Doehlert Matrix. The codified values are in brackets.

\begin{tabular}{|c|c|c|c|c|c|c|}
\hline Case & $\begin{array}{c}\mathrm{T}_{\mathrm{R}}\left(\mathrm{x}_{1}\right) \\
\left({ }^{\circ} \mathrm{C}\right)\end{array}$ & $\begin{array}{c}\operatorname{ThOD}_{\text {feed }}\left(\mathrm{x}_{2}\right) \\
\left(\mathrm{g} \cdot \mathrm{L}^{-1}\right)\end{array}$ & $\begin{array}{c}\mathrm{T}_{\text {output }}\left(\mathrm{x}_{3}\right) \\
\quad\left({ }^{\circ} \mathrm{C}\right)\end{array}$ & $\begin{array}{c}\mathrm{HP}_{\text {excess }}\left(\mathrm{x}_{4}\right) \\
(\%)\end{array}$ & $\begin{array}{c}\tau\left(x_{5}\right) \\
\left(\mathrm{g} \cdot \mathrm{h} \cdot \mathrm{mol}^{-1}\right)\end{array}$ & $\begin{array}{c}\mathrm{T}_{\text {input }}\left(\mathrm{x}_{6}\right) \\
\left({ }^{\circ} \mathrm{C}\right)\end{array}$ \\
\hline 1 & $90(0)$ & $13(0)$ & $45(0)$ & $100(0)$ & $165(0)$ & $20(0)$ \\
\hline 2 & $130(1)$ & $13(0)$ & $45(0)$ & $100(0)$ & $165(0)$ & $20(0)$ \\
\hline 3 & $50(-1)$ & $13(0)$ & $45(0)$ & $100(0)$ & $165(0)$ & $20(0)$ \\
\hline 4 & $110(0.5)$ & $23(0.866)$ & $45(0)$ & $100(0)$ & $165(0)$ & $20(0)$ \\
\hline 5 & $70(-0.5)$ & $23(0.866)$ & $45(0)$ & $100(0)$ & $165(0)$ & $20(0)$ \\
\hline 6 & $110(0.5)$ & $2(-0.867)$ & $45(0)$ & $100(0)$ & $165(0)$ & $20(0)$ \\
\hline 7 & $70(-0.5)$ & $2(-0.867)$ & $45(0)$ & $100(0)$ & $165(0)$ & $20(0)$ \\
\hline 8 & $110(0.5)$ & $16(0.288)$ & $60(0.816)$ & $100(0)$ & $165(0)$ & $20(0)$ \\
\hline 9 & $70(-0.5)$ & $16(0.288)$ & $60(0.816)$ & $100(0)$ & $165(0)$ & $20(0)$ \\
\hline 10 & $110(0.5)$ & $9(-0.289)$ & $30(-0.817)$ & $100(0)$ & $165(0)$ & $20(0)$ \\
\hline 11 & $70(-0.5)$ & $9(-0.289)$ & $30(-0.817)$ & $100(0)$ & $165(0)$ & $20(0)$ \\
\hline 12 & $90(0)$ & $20(0.577)$ & $30(-0.817)$ & $100(0)$ & $165(0)$ & $20(0)$ \\
\hline 13 & $90(0)$ & $5(-0.578)$ & $60(0.816)$ & $100(0)$ & $165(0)$ & $20(0)$ \\
\hline 14 & $110(0.5)$ & $16(0.288)$ & $48.7(0.204)$ & $150(0.79)$ & $165(0)$ & $20(0)$ \\
\hline 15 & $70(-0.5)$ & $16(0.288)$ & $48.7(0.204)$ & $150(0.79)$ & $165(0)$ & $20(0)$ \\
\hline 16 & $90(0)$ & $5(-0.578)$ & $48.7(0.204)$ & $150(0.79)$ & $165(0)$ & $20(0)$ \\
\hline 17 & $90(0)$ & $13(0)$ & $33.7(-0.613)$ & $150(0.79)$ & $165(0)$ & $20(0)$ \\
\hline 18 & $110(0.5)$ & $9(-0.289)$ & $41.2(-0.205)$ & $50(-0.791)$ & $165(0)$ & $20(0)$ \\
\hline 19 & $70(-0.5)$ & $9(-0.289)$ & $41.2(-0.205)$ & $50(-0.791)$ & $165(0)$ & $20(0)$ \\
\hline 20 & $90(0)$ & $20(0.577)$ & $41.2(-0.205)$ & $50(-0.791)$ & $165(0)$ & $20(0)$ \\
\hline 21 & $90(0)$ & $13(0)$ & $56.2(0.612)$ & $50(-0.791)$ & $165(0)$ & $20(0)$ \\
\hline 22 & $110(0.5)$ & $16(0.288)$ & 48.7 (0.204) & $110(0.158)$ & $94(0.774)$ & $20(0)$ \\
\hline 23 & $70(-0.5)$ & $16(0.288)$ & $48.7(0.204)$ & $110(0.158)$ & $94(0.774)$ & $20(0)$ \\
\hline 24 & $90(0)$ & $5(-0.578)$ & $48.7(0.204)$ & $110(0.158)$ & $94(0.774)$ & $20(0)$ \\
\hline 25 & $90(0)$ & $13(0)$ & $33.7(-0.613)$ & $110(0.158)$ & $94(0.774)$ & $20(0)$ \\
\hline 26 & $90(0)$ & $13(0)$ & $45(0)$ & $59(-0.633)$ & $94(0.774)$ & $20(0)$ \\
\hline 27 & $110(0.5)$ & $9(-0.289)$ & $41.2(-0.205)$ & $89(-0.159)$ & $235(-0.775)$ & $20(0)$ \\
\hline 28 & $70(-0.5)$ & $9(-0.289)$ & $41.2(-0.205)$ & $89(-0.159)$ & $235(-0.775)$ & $20(0)$ \\
\hline 29 & $90(0)$ & $20(0.577)$ & $41.2(-0.205)$ & $89(-0.159)$ & $235(-0.775)$ & $20(0)$ \\
\hline 30 & $90(0)$ & $13(0)$ & $56.2(0.612)$ & $89(-0.159)$ & $235(-0.775)$ & $20(0)$ \\
\hline 31 & $90(0)$ & $13(0)$ & $45(0)$ & $140(0.632)$ & $235(-0.775)$ & $20(0)$ \\
\hline 32 & $110(0.5)$ & $16(0.288)$ & $48.7(0.204)$ & $110(0.158)$ & $153(0.129)$ & $25(0.763)$ \\
\hline 33 & $70(-0.5)$ & $16(0.288)$ & $48.7(0.204)$ & $110(0.158)$ & $153(0.129)$ & $25(0.763)$ \\
\hline 34 & $90(0)$ & $5(-0.578)$ & $48.7(0.204)$ & $110(0.158)$ & $153(0.129)$ & $25(0.763)$ \\
\hline 35 & $90(0)$ & $13(0)$ & $33.7(-0.613)$ & $110(0.158)$ & $153(0.129)$ & $25(0.763)$ \\
\hline 36 & $90(0)$ & $13(0)$ & $45(0)$ & $59(-0.633)$ & $153(0.129)$ & $25(0.763)$ \\
\hline 37 & $90(0)$ & $13(0)$ & $45(0)$ & $100(0)$ & $223(-0.646)$ & $25(0.763)$ \\
\hline 38 & $110(0.5)$ & $9(-0.289)$ & $41.2(-0.205)$ & $89(-0.159)$ & $176(-0.13)$ & $15(-0.764)$ \\
\hline 39 & $70(-0.5)$ & $9(-0.289)$ & $41.2(-0.205)$ & $89(-0.159)$ & $176(-0.13)$ & $15(-0.764)$ \\
\hline 40 & $90(0)$ & $20(0.577)$ & $41.2(-0.205)$ & $89(-0.159)$ & $176(-0.13)$ & $15(-0.764)$ \\
\hline 41 & $90(0)$ & $13(0)$ & $56.2(0.612)$ & $89(-0.159)$ & $176(-0.13)$ & $15(-0.764)$ \\
\hline 42 & $90(0)$ & $13(0)$ & $45(0)$ & $140(0.632)$ & $176(-0.13)$ & $15(-0.764)$ \\
\hline 43 & $90(0)$ & $13(0)$ & $45(0)$ & $100(0)$ & $106(0.645)$ & $15(-0.764)$ \\
\hline
\end{tabular}

\section{Results and Discussion}

\subsection{Kinetic Model Validation}

Prior to the simulation of the CWPO process, it is necessary to confirm that the evolution of the reactants (i.e., phenol and $\mathrm{H}_{2} \mathrm{O}_{2}$ ) and the oxidized intermediates can be successfully computed, and that the results obtained reproduced the experimental ones. Based on the elementary reaction set introduced in the simulator (Table S1), the empirical kinetic equation was defined for each organic species, shown in Equation (1), with the kinetic constants estimated for the CWPO with a carbon black catalyst [40] and the thermodynamic data selected (Table S2 of the Supplementary Material); calculations were performed in a batch reactor with Aspen Plus under the following selected operating 
conditions: $\mathrm{C}_{\text {Phenol, } 0}=1 \mathrm{~g} \cdot \mathrm{L}^{-1}, \mathrm{C}_{\mathrm{H}_{2} \mathrm{O}_{2}, 0}=5 \mathrm{~g} \cdot \mathrm{L}^{-1}, \mathrm{pH}_{0}=6, \mathrm{~W}=4 \mathrm{~g}$ cat and $\mathrm{T}=90{ }^{\circ} \mathrm{C}$ and at different reaction times in order to mimic the experimental conditions.

The results obtained in the simulations, in terms of the temporal evolution of the molar fraction of phenol and the aromatic intermediates (BQ, CTL, HQ and RS), are provided in Figure 2a. The profiles for the organic acids, also calculated, are not shown for simplicity. Besides, the $\mathrm{H}_{2} \mathrm{O}_{2}$ molar fraction calculated from the production rate of each organic compound and the stoichiometric coefficient of the corresponding equation (Table S1) is provided in Figure 2b. As can be seen in Figure 2c, the molar fractions calculated by the simulation agree with the experimental data obtained in our previous work [40]. The kinetic model implemented in the simulator is valid to describe the complex reaction network of the phenol CWPO in the presence of carbon black catalysts. Note that the kinetic model is particular for each catalyst, since the specificity of each active site can lead to a different reaction networks and rate equations.

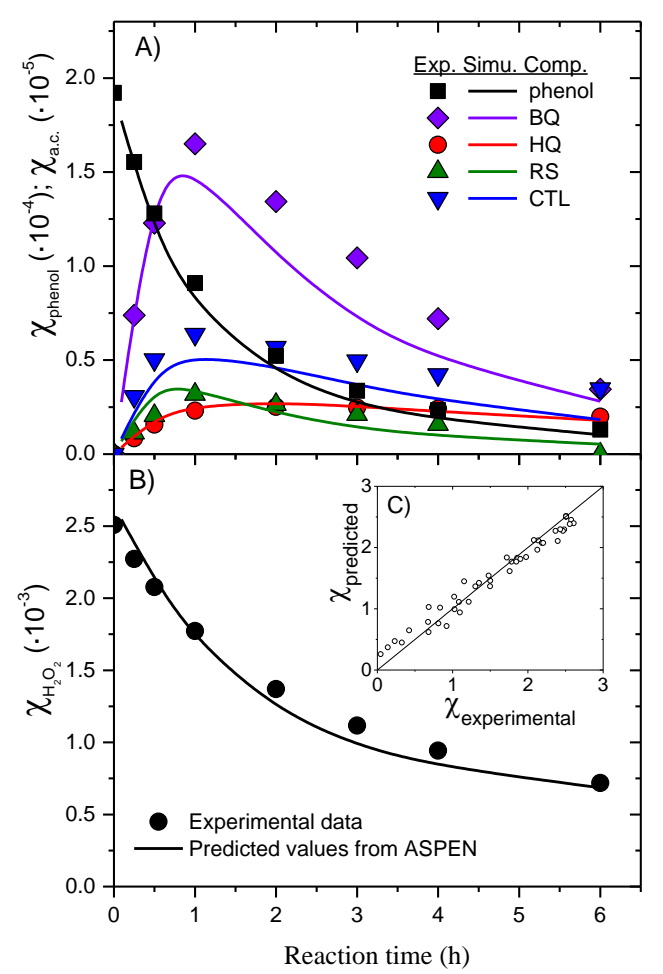

Figure 2. Experimental results (symbols) and those predicted by the ASPEN Plus ${ }^{\circledR}$ v11 simulator (curves) time course of the molar fraction of aromatic compounds (A) and $\mathrm{H}_{2} \mathrm{O}_{2}(\mathbf{B})$ in a batch reactor at $\mathrm{C}_{\text {Phenol, } 0}=1 \mathrm{~g} \mathrm{~L}^{-1}, \mathrm{C}_{\mathrm{H} 2 \mathrm{O} 2,0}=5 \mathrm{~g} \mathrm{~L}^{-1}, \mathrm{~W}=4 \mathrm{~g}_{\text {cat }}, \mathrm{pH}_{0}=6$ and $\mathrm{T}=90{ }^{\circ} \mathrm{C}$; parity plot of $\mathrm{H}_{2} \mathrm{O}_{2}$ molar fraction $(\mathbf{C})$.

\subsection{CWPO Performance}

The values of the response variables (i.e., $x_{\text {phenol }}, X_{\text {ThOD }}, X_{T O C}, X_{\mathrm{H}_{2} \mathrm{O}_{2}}, \eta_{\mathrm{H}_{2} \mathrm{O}_{2}}$ and $\eta_{\mathrm{E}}$ ) obtained in the 43 simulation cases conducted under the operating conditions defined by the Doehlert Matrix (Table 1$)$ are given in Table 2 . As observed, total pollutant removal $\left(X_{\text {phenol }}>99 \%\right)$ is only achieved in Cases 2, 4, 14, 31 and 32, in which $\mathrm{X}_{\mathrm{ThOD}}$ and $\mathrm{X}_{\mathrm{TOC}}$ are also high, above $75 \%$ and $71 \%$, respectively, as is $\eta_{\mathrm{H}_{2} \mathrm{O}_{2}}$, between $69 \%$ and $79 \%$. There is always remaining ThOD and TOC in the reactor outlet. In fact, the maximum conversions are obtained at the highest reaction temperature of $110{ }^{\circ} \mathrm{C}$, in Cases 4 and 14 , where both $X_{T h O D} \sim 78 \%$ and $X_{T O C} \sim 74 \%$ are achieved. 
Table 2. Response variables obtained with the six-factor Doehlert Matrix.

\begin{tabular}{|c|c|c|c|c|c|c|}
\hline Case & $\underset{(\%)}{X_{\text {phenol }}}$ & $\underset{(\%)}{X_{\text {ThOD }}}$ & $\begin{array}{c}\mathrm{X}_{\mathrm{TOC}} \\
(\%)\end{array}$ & $\begin{array}{c}\mathrm{X}_{\mathrm{H}_{2} \mathrm{O}_{2}} \\
(\%)\end{array}$ & $\begin{array}{c}\eta_{\mathrm{H}_{2} \mathrm{O}_{2}} \\
(\%)\end{array}$ & $\begin{array}{c}\eta_{E} \\
(\%)\end{array}$ \\
\hline 1 & 92.4 & 62.7 & 57.8 & 67.5 & 73.13 & 110.0 \\
\hline 2 & 99.1 & 76.9 & 72.9 & 78.6 & 79.35 & 110.4 \\
\hline 3 & 63.0 & 23.1 & 17.2 & 34.0 & 43.29 & 62.5 \\
\hline 4 & 99.9 & 77.8 & 73.8 & 81.9 & 77.09 & 152.2 \\
\hline 5 & 97.6 & 64.0 & 58.4 & 76.2 & 65.59 & 178.6 \\
\hline 6 & 23.0 & 9.3 & 7.2 & 9.7 & 63.83 & 70.1 \\
\hline 7 & 7.9 & 2.4 & 1.7 & 2.9 & 47.90 & 48.3 \\
\hline 8 & 99.0 & 76.3 & 72.2 & 79.5 & 77.72 & 110.6 \\
\hline 9 & 91.0 & 52.0 & 45.9 & 61.8 & 63.49 & 93.4 \\
\hline 10 & 90.4 & 65.3 & 61.0 & 67.6 & 77.23 & 112.4 \\
\hline 11 & 66.2 & 28.7 & 23.1 & 34.2 & 57.67 & 99.3 \\
\hline 12 & 98.6 & 73.5 & 69.1 & 79.6 & 74.18 & 169.3 \\
\hline 13 & 56.3 & 26.9 & 22.4 & 29.1 & 65.95 & 50.9 \\
\hline 14 & 100.0 & 78.0 & 74.1 & 60.5 & 69.76 & 125.7 \\
\hline 15 & 97.7 & 64.2 & 58.6 & 58.0 & 57.67 & 137.2 \\
\hline 16 & 70.8 & 38.6 & 33.6 & 29.1 & 65.94 & 70.3 \\
\hline 17 & 98.5 & 73.4 & 68.9 & 57.2 & 68.71 & 134.9 \\
\hline 18 & 65.5 & 39.6 & 35.5 & 80.1 & 75.80 & 89.8 \\
\hline 19 & 42.1 & 15.5 & 11.6 & 33.7 & 58.68 & 67.0 \\
\hline 20 & 79.1 & 46.5 & 41.3 & 95.2 & 74.26 & 120.8 \\
\hline 21 & 69.8 & 37.6 & 32.6 & 77.2 & 72.15 & 74.9 \\
\hline 22 & 97.6 & 74.4 & 70.3 & 71.0 & 77.15 & 121.1 \\
\hline 23 & 83.6 & 43.2 & 37.0 & 47.7 & 60.32 & 102.8 \\
\hline 24 & 42.7 & 18.2 & 14.6 & 18.2 & 62.41 & 62.9 \\
\hline 25 & 86.1 & 54.5 & 49.3 & 54.0 & 71.24 & 118.8 \\
\hline 26 & 65.5 & 33.9 & 29.0 & 58.9 & 70.48 & 87.4 \\
\hline 27 & 91.8 & 66.9 & 62.7 & 76.6 & 77.86 & 101.7 \\
\hline 28 & 72.6 & 33.2 & 27.3 & 43.2 & 60.18 & 81.9 \\
\hline 29 & 98.5 & 73.4 & 69.0 & 87.1 & 75.40 & 153.9 \\
\hline 30 & 93.7 & 64.7 & 59.8 & 76.7 & 74.31 & 96.3 \\
\hline 31 & 99.3 & 75.3 & 71.1 & 62.9 & 69.22 & 121.5 \\
\hline 32 & 99.5 & 77.0 & 73.0 & 74.5 & 76.86 & 130.5 \\
\hline 33 & 91.9 & 53.5 & 47.4 & 59.6 & 62.46 & 131.3 \\
\hline 34 & 57.5 & 27.7 & 23.2 & 27.7 & 65.61 & 71.3 \\
\hline 35 & 93.5 & 64.4 & 59.5 & 64.4 & 72.55 & 136.4 \\
\hline 36 & 75.1 & 42.5 & 37.4 & 74.0 & 72.66 & 101.1 \\
\hline 37 & 95.4 & 67.5 & 62.7 & 72.8 & 73.70 & 122.1 \\
\hline 38 & 88.4 & 62.9 & 58.6 & 71.6 & 77.45 & 94.8 \\
\hline 39 & 64.5 & 27.6 & 22.1 & 35.7 & 58.42 & 70.3 \\
\hline 40 & 97.5 & 71.4 & 66.8 & 84.2 & 75.12 & 141.3 \\
\hline 41 & 90.7 & 60.3 & 55.2 & 71.0 & 73.61 & 86.6 \\
\hline 42 & 98.2 & 72.9 & 68.4 & 59.7 & 69.76 & 111.3 \\
\hline 43 & 85.5 & 53.7 & 48.6 & 58.0 & 71.89 & 96.5 \\
\hline
\end{tabular}

Noteworthily, the self-sustaining thermal condition $\left(\eta_{E}>100 \%\right)$ is achievable under a wide range of operating conditions (in 24 scenarios of the 43 simulated, see Table 2), including the whole ranges of values explored for $\mathrm{T}_{\text {output }}\left(30-60^{\circ} \mathrm{C}\right), \mathrm{T}_{\text {input }}\left(15-25^{\circ} \mathrm{C}\right), \mathrm{HP}$ excess $(50 \%-100 \%)$ and $\tau(94$ and $\left.235 \mathrm{~g}_{\text {cat }} \cdot \mathrm{h} \cdot \mathrm{mol}_{\text {phenol }}{ }^{-1}\right)$. This is an important aspect because in these 24 scenarios, the CWPO unit can be operated without any external heat supply under steady state operation. The $\mathrm{ThOD}_{\text {feed }}$ seems to be the most influential variable affecting the energetic efficiency (see Figure S1 of the Supplementary Material). Additionally, it is possible to observe a linear relationship between $\eta_{E}$ and $T h O D_{\text {feed }}$, regardless of the values of the rest of the operating conditions $-T_{R}, T_{\text {output }}, H P_{\text {excess }}, \tau$ and $T_{\text {input }}$ (see Figure $S 1 d$ of the Supplementary Material). This can be explained because the more the organic matter that is converted in the reactor (by the oxidation of phenol and its intermediates), the more heat is generated (the same 
tendency was observed with respect to $\mathrm{X}_{\mathrm{TOC}}$ ). However, $\mathrm{ThOD}_{\text {feed }}$ should not be the only variable taken into account, as exemplified by Cases 36 and 30. In the former, $5.4 \mathrm{~g} \mathrm{~L}^{-1}$ of ThOD was removed in the reactor $\left(\mathrm{ThOD}_{\text {feed }}=13 \mathrm{~g} / \mathrm{L}\right.$ and $\mathrm{X}_{\mathrm{ThOD}}=42 \%$ ) and the energy efficiency was $101 \%$, while in the latter, $8.4 \mathrm{~g} \mathrm{~L}^{-1}$ of ThOD was removed in the reactor $\left(\mathrm{ThOD}_{\text {feed }}=13 \mathrm{~g} \cdot \mathrm{L}^{-1}\right.$ and $\left.\mathrm{X}_{\mathrm{ThOD}}=64.7 \%\right)$ while $\eta_{\mathrm{E}}$ was lower than $100 \%$. Elucidating the interactive effects of the operating variables on the responses will necessitate assessing the mathematical adjustment of the data to the quadratic model in Equation (6), as addressed below.

Finally, the minimum $X_{\text {phenol }}, X_{\text {ThOD }}$ and $X_{\text {TOC }}$ values that guarantee the self-sustaining thermal CWPO condition $\left(\eta_{E}>100 \%\right.$ ) are 75,42 and $37 \%$, respectively (Case 36 of Table 2 ). In this case, an energy efficiency of $101 \%$ is achieved at $\mathrm{ThOD}_{\text {feed }}=13 \mathrm{~g} / \mathrm{L}, \mathrm{HP}_{\text {excess }}=60 \%, \tau=153 \mathrm{~g}_{\text {cat }} \cdot \mathrm{h} \cdot \mathrm{mol}_{\text {phenol }}{ }^{-1}$, $\mathrm{T}_{\mathrm{R}}=90^{\circ} \mathrm{C}, \mathrm{T}_{\text {input }}=45^{\circ} \mathrm{C}$ and $\mathrm{T}_{\text {input }}=25^{\circ} \mathrm{C}$.

\subsection{Mathematical Modeling and Response Surface Plots}

The ANOVA results of quadratic model for $x_{\text {phenol}}, x_{T h O D}, x_{T O C}, x_{\mathrm{H}_{2} \mathrm{O}_{2}}, \eta_{\mathrm{H}_{2} \mathrm{O}_{2}}$ and $\eta_{E}$ are summarized in Table 3, along with the estimated coefficient values. The F-distribution and $p$-values for each estimated coefficient are collected in order to compute their statistical significance (coefficient excluded if $p$-value $>0.30$ ). As observed, the F of Fisher is higher than the $p$-value for all the regressions, so the desired model significance is fulfilled. In fact, the parity plot depicted in Figure 3 shows good agreement.

Table 3. Analysis of variance and significant coefficient values ( $p$-value $<0.30$ ) for the six responses studies.

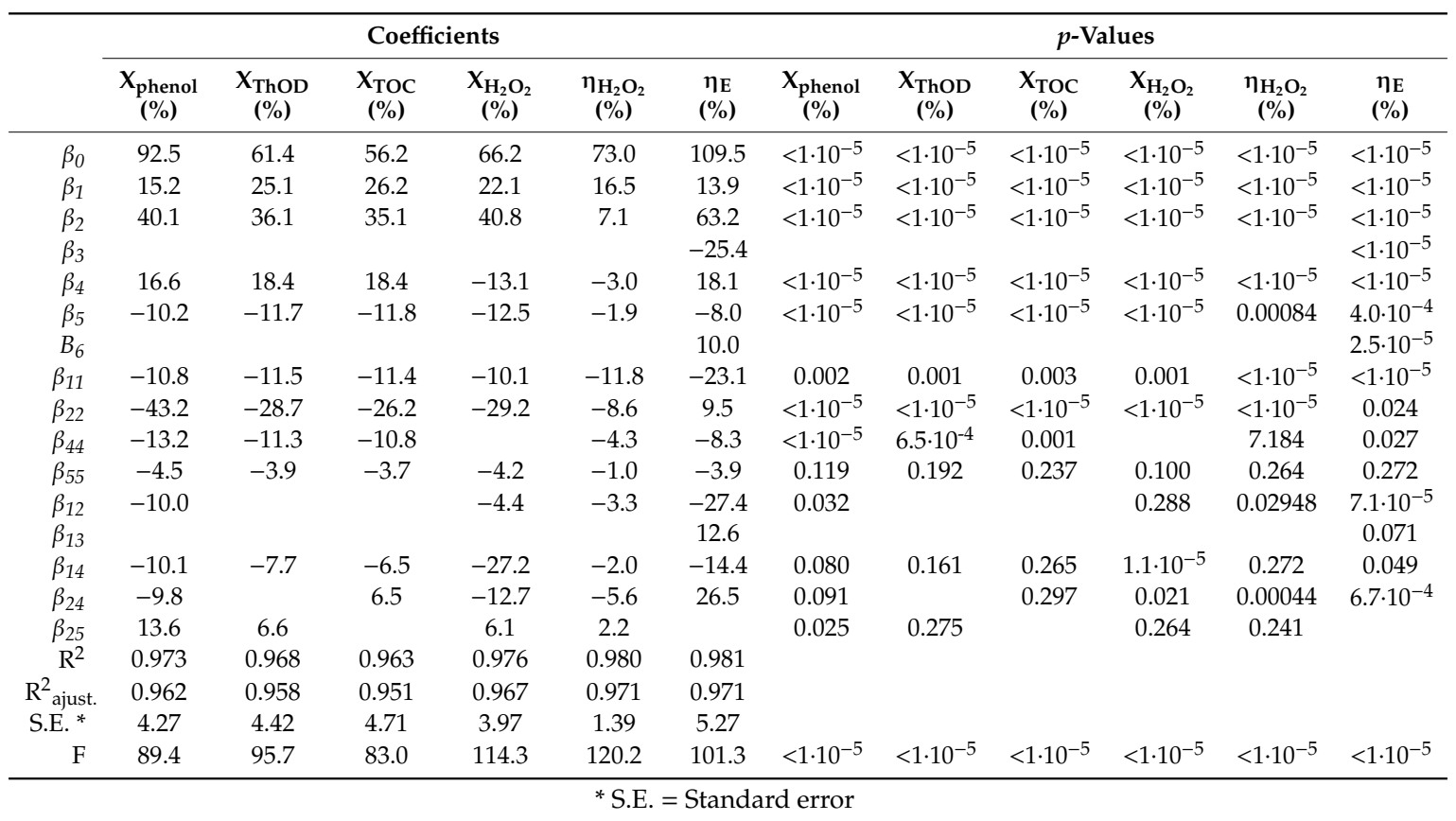




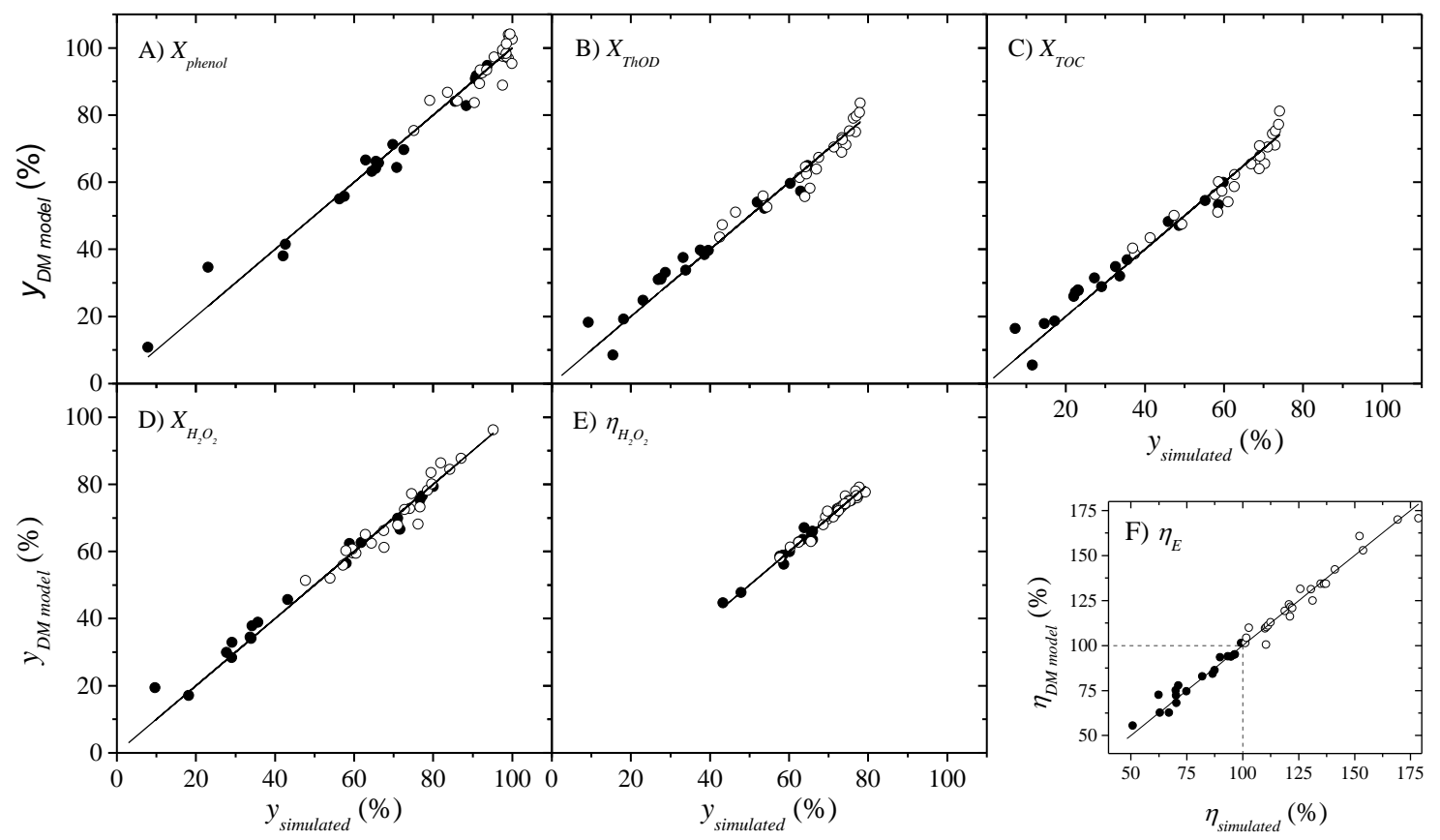

Figure 3. Parity plots comparing the six response variables $(\mathbf{A}-\mathbf{F})$ predicted by the quadratic model and by the ASPEN Plus ${ }^{\circledR}$ v11 simulator. Open symbols represent the cases under autothermal operation.

In general, the conversion response equations are similar since all the conversions (i.e., $X_{\text {phenol }}$, $X_{\text {ThOD }}, X_{\text {TOC }}$ and $\left.X_{\mathrm{H}_{2} \mathrm{O}_{2}}\right)$ take high values upon increasing the $\mathrm{T}_{\mathrm{R}}\left(\beta_{1}=15.2-22.1\right)$, ThOD feed $\left(\beta_{2}\right.$ $=35.1-40.8)$ and $\tau\left(-\beta_{5}=10.2-12.5\right)$. Interestingly, $X_{\text {phenol }}, X_{\text {ThOD }}$ and $X_{\text {TOC }}$ also increase upon increasing $\mathrm{HP}_{\text {excess }}\left(\beta_{4}=16.6-18.4\right)$, whereas the $\mathrm{X}_{\mathrm{H}_{2} \mathrm{O}_{2}}$ is decreased by increasing $\mathrm{HP}_{\text {excess }}\left(\beta_{4}=-13.1\right)$, which indicates that a higher concentration of radical species in the reactor medium increases the organic compound oxidation rates but also favors the conversion of the radical scavenging recombination into $\mathrm{H}_{2} \mathrm{O}_{2}$. The most influential variable for the conversions is ThOD feed $\left(\beta_{2}>\beta_{\mathrm{i} \neq 2}\right)$, which is in agreement with the previous discussion.

Regarding $\eta_{\mathrm{H}_{2} \mathrm{O}_{2}}, \mathrm{~T}_{\mathrm{R}}$ is the variable with the greatest influence $\left(\beta_{1}>\beta_{\mathrm{i} \neq 1}\right)$ followed by ThOD $\mathrm{D}_{\text {feed }}$. According to this, a high reaction temperature improves the efficient consumption of $\mathrm{H}_{2} \mathrm{O}_{2}$ in CWPO, as has been already reported for the Fenton process [52]. To a lesser extent, a high concentration of ThOD $D_{\text {feed }}$ also favors the efficient use of the oxidant. Note that doses of $\mathrm{H}_{2} \mathrm{O}_{2}$ above the stoichiometric ones, $\mathrm{HP}_{\text {excess }}>100 \%$, do not induce a significant detriment to the efficiency.

In the case of $\eta_{\mathrm{E}}$, the significant operating conditions are $\mathrm{T}_{\text {input }}, \mathrm{T}_{\text {output }}$ and $\mathrm{ThOD}_{\text {feed }}$-in particular, ThOD $D_{\text {feed }}\left(\beta_{2}=63.2\right.$ vs. $\left.\left|\beta_{\mathrm{i} \neq 2}\right|=8-25.4\right)$. Expectedly, a higher initial pollutant concentration in the feed stream leads to higher conversions, and thus, more heat is released in the reactor. It is also noteworthy that while $T_{\text {input }}$ has a positive effect $\left(\beta_{6}=10.0\right), T_{\text {output }}$ has a negative one $\left(\beta_{3}=-25.4\right)$; this means that $\eta_{\mathrm{E}}$ is increased by decreasing the heat recovery from the output stream. For this response, the effect of this temperature ( $\left.\mathrm{T}_{\text {output }}\right)$ is found to be more significant than the effect of the $\mathrm{T}_{\mathrm{R}}, \mathrm{ThOD}_{\text {feed }}, \mathrm{HP}_{\text {excess }}$ or $\tau\left(\beta_{6}>\beta_{1}, \beta_{3}, \beta_{4}, \beta_{5}\right)$.

All the fitted response variables, i.e., $X_{\text {phenol }}, X_{\text {ThOD }}, X_{T O C}, X_{\mathrm{H}_{2} \mathrm{O}_{2}}, \eta_{\mathrm{H}_{2} \mathrm{O}_{2}}$ and $\eta_{\mathrm{E}}$, show significant second-order $\left(\beta_{\mathrm{ii}}\right)$ and interaction $\left(\beta_{\mathrm{ij}}\right)$ coefficients, so it will be important to consider all the operating conditions to seek optimal performance. To gain an insight into this, the response surface plots and 2-D contour plots showing the effects of $\mathrm{T}_{\mathrm{R}}$ and $\mathrm{ThOD}_{\text {feed }}$ and also, $\mathrm{HP}_{\text {excess }}$ and $\mathrm{ThOD}_{\text {feed }}$ on the responses $X_{\text {phenol }}, X_{\text {ThOD }}, \eta_{\mathrm{H}_{2} \mathrm{O}_{2}}$ and $\eta_{\mathrm{E}}$ are shown in Figures 4 and 5 , respectively.

As can be seen, for $\mathrm{X}_{\text {phenol }}(\mathrm{A})$ and $\mathrm{X}_{\mathrm{ThOD}}(\mathrm{B})$, the increase in $\mathrm{T}_{\mathrm{R}}$ and $\mathrm{HP}_{\text {excess }}$ up to $100{ }^{\circ} \mathrm{C}$ and $100 \%$ of the stoichiometric dose, respectively, enhances the conversions, whereas $\mathrm{ThOD}_{\text {feed }}$ values above $16 \mathrm{~g} \cdot \mathrm{L}^{-1}$ have a clearly negative impact. This means that $X_{\text {phenol }}$ and $X_{\text {ThOD }}$ can be optimized to achieve their maximum values (100 and $78 \%$, respectively) inside the operation window considered. 
Regarding the $\eta_{\mathrm{H}_{2} \mathrm{O}_{2}}$, its variation is higher with $\mathrm{T}_{\mathrm{R}}$ than $\mathrm{ThOD}_{\text {feed }}$ and $\mathrm{HP}_{\text {excess, }}$, as expected, but the three variables must be considered for the optimization of $\eta_{\mathrm{H}_{2} \mathrm{O}_{2}}$. It is remarkable that the thermal self-sustaining conditions $\left(\eta_{\mathrm{E}} \geq 100 \%\right)$ can be achieved across a wide range of $\eta_{\mathrm{H}_{2} \mathrm{O}_{2}}$ values $(47 \%-81 \%)$ (see Figures $4 \mathrm{c}$ and $5 \mathrm{c}$ ). Lastly, $\eta_{\mathrm{E}} \geq 100 \%$ are obtained at $\mathrm{T}_{\mathrm{R}}$ from 80 to $100{ }^{\circ} \mathrm{C}$ and $\mathrm{ThOD}_{\text {feed }}$ values above $9 \mathrm{~g} \cdot \mathrm{L}^{-1}$ (Figure $4 \mathrm{~d}$ ). The effect of the $\mathrm{HP}_{\text {excess }}$ is not as significant as that of $\mathrm{ThOD}_{\text {feed }}$ (Figure $5 \mathrm{~d}$ ) for this response.

A)

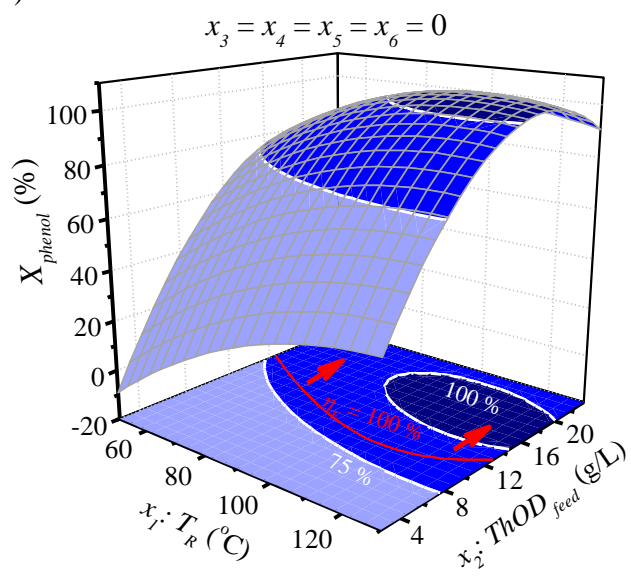

C)

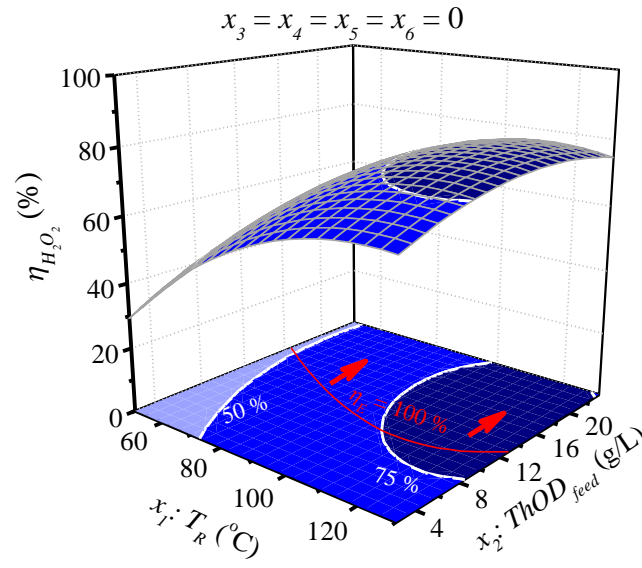

B)

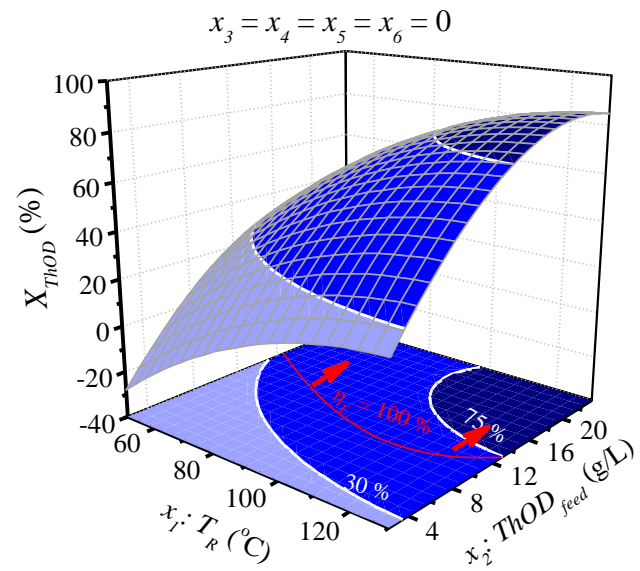

D)

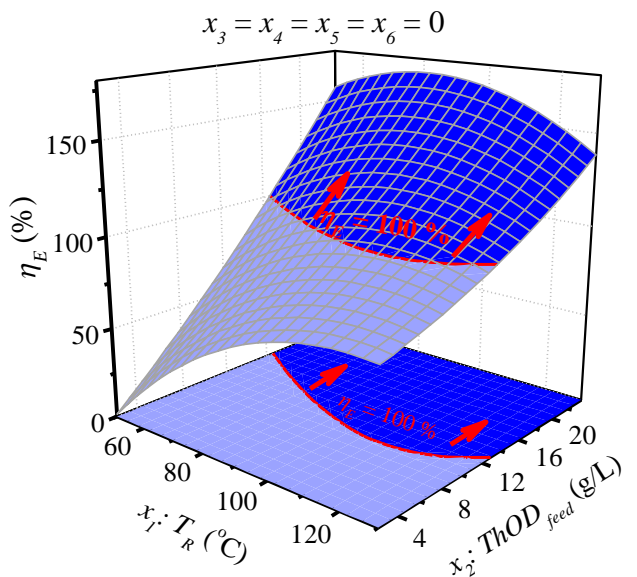

Figure 4. Response surfaces, contour plots and surface projections for $X_{\text {phenol }}(A), X_{\text {ThOD }}(\mathbf{B}), \eta_{\mathrm{H}_{2} \mathrm{O}_{2}}(\mathbf{C})$ and $\eta_{E}(D)$ as predicted by the quadratic models at different $T_{R}$ and $T h O D_{\text {feed }}$ values under $T_{\text {output }}=$ $45^{\circ} \mathrm{C}\left(\mathrm{x}_{3}=0\right), \mathrm{HP}_{\text {excess }}=100\left(\mathrm{x}_{4}=0\right), \tau=165 \mathrm{~g} \mathrm{~h} \mathrm{~mol}^{-1}\left(\mathrm{x}_{5}=0\right)$ and $\mathrm{T}_{\text {input }}=20^{\circ} \mathrm{C}\left(\mathrm{x}_{6}=0\right)$. 
A)

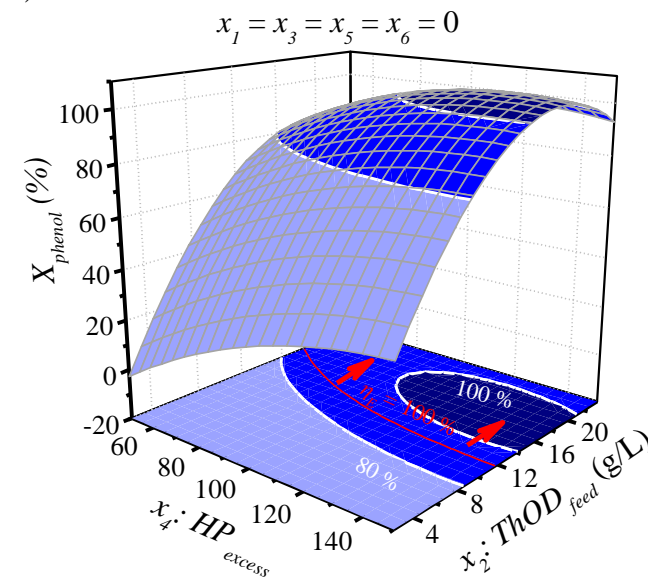

C)

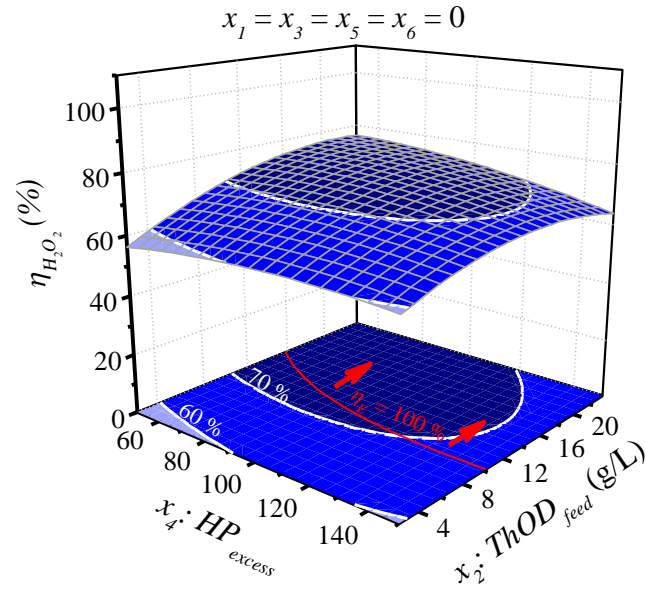

B)

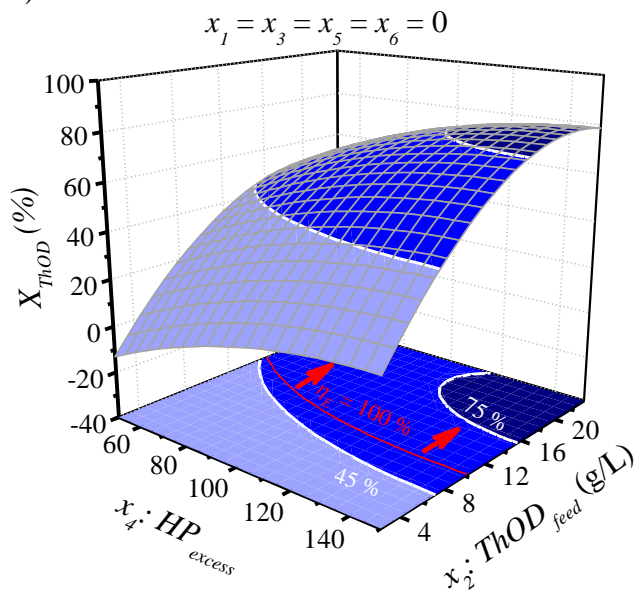

D)

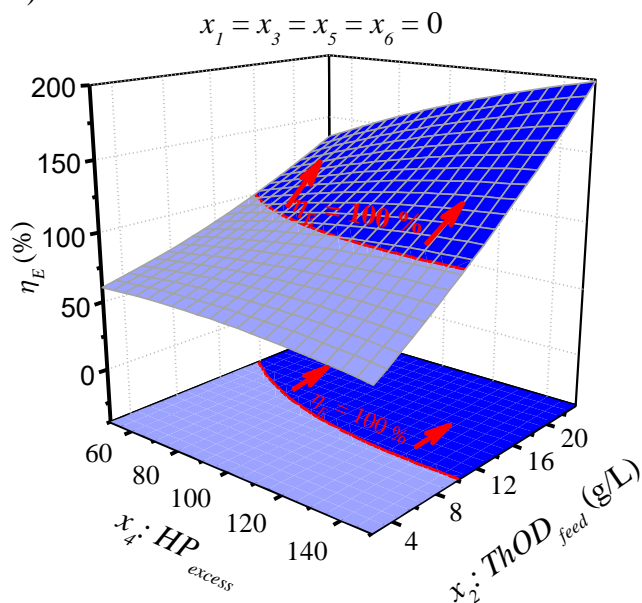

Figure 5. Response surfaces, contour plots and surface projections for $X_{\text {phenol }}(\mathbf{A}), X_{\text {ThOD }}(\mathbf{B}), \eta_{\mathrm{H}_{2} \mathrm{O}_{2}}$ (C) and $\eta_{\mathrm{E}}(\mathbf{D})$ as predicted by the quadratic models at different $\mathrm{HP}_{\text {excess }}$ and $\mathrm{ThOD}_{\text {feed }}$ values under $\mathrm{T}_{\text {output }}=90^{\circ} \mathrm{C}\left(\mathrm{x}_{1}=0\right), \mathrm{T}_{\text {output }}=45^{\circ} \mathrm{C}\left(\mathrm{x}_{3}=0\right), \tau=165 \mathrm{~g} \cdot \mathrm{h} \cdot \mathrm{mol}^{-1}\left(\mathrm{x}_{5}=0\right)$ and $\mathrm{T}_{\text {input }}=20{ }^{\circ} \mathrm{C}\left(\mathrm{x}_{6}=0\right)$.

\subsection{Multi-Criteria Optimization of CWPO Performance}

The operating conditions necessary to obtain the highest $X_{\text {phenol}}, X_{T h O D}, X_{T O C}, X_{\mathrm{H}_{2} \mathrm{O}_{2}}, \eta_{\mathrm{H}_{2} \mathrm{O}_{2}}$ or $\eta_{\mathrm{E}}$ upon CWPO in the presence of carbon black catalysts, derived from the optimization of the quadratic model selected in Equation (6), for each response are provided in Table 4.

Table 4. Optimal operating conditions for each individual response.

\begin{tabular}{|c|c|c|c|c|c|c|c|}
\hline \multicolumn{2}{|c|}{ Responses } & \multicolumn{6}{|c|}{ Operating Conditions } \\
\hline Variable & $\begin{array}{c}\text { Optimized Value } \\
(\%)\end{array}$ & $\begin{array}{c}\mathrm{T}_{\mathrm{R}}\left(\mathrm{x}_{1}\right) \\
\left({ }^{\circ} \mathrm{C}\right)\end{array}$ & $\begin{array}{l}\operatorname{ThOD}_{\text {feed }}\left(\mathrm{x}_{2}\right) \\
\left(\mathrm{g} \mathrm{L}^{-1}\right)\end{array}$ & $\begin{array}{c}\mathrm{T}_{\mathrm{S}-06}\left(\mathrm{x}_{3}\right) \\
\left({ }^{\circ} \mathrm{C}\right)\end{array}$ & $\begin{array}{c}\mathrm{HP}_{\text {excess }}\left(\mathrm{x}_{4}\right) \\
(\%)\end{array}$ & $\begin{array}{c}\tau\left(x_{5}\right) \\
\left(g \cdot h \cdot \mathrm{mol}^{-1}\right)\end{array}$ & $\begin{array}{c}\mathrm{T}_{\mathrm{S}-03}\left(\mathrm{x}_{6}\right) \\
\left({ }^{\circ} \mathrm{C}\right)\end{array}$ \\
\hline$X_{\text {phenol }}$ & $>100.0^{*}$ & $106(0.406)$ & $16.2(0.256)$ & n.a. ** & $123(0.377)$ & $232(-0.747)$ & n.a. \\
\hline$X_{\text {ThOD }}$ & 91.6 & $116(0.672)$ & $20.8(0.628)$ & n.a. & $137(0.586)$ & $235(-0.775)$ & n.a. \\
\hline $\mathrm{X}_{\mathrm{TOC}}$ & 96.1 & $126(0.921)$ & $22.5(0.768)$ & n.a. & $150(0.791)$ & $235(-0.775)$ & n.a. \\
\hline $\mathrm{X}_{\mathrm{H}_{2} \mathrm{O}_{2}}$ & $>100.0^{*}$ & $130(1.000)$ & $21.9(0.715)$ & n.a. & $50(-0.791)$ & $235(-0.775)$ & n.a. \\
\hline$\eta_{\mathrm{H}_{2} \mathrm{O}_{2}}$ & $>100.0^{*}$ & $130(1.000)$ & $23.8(0.866)$ & n.a. & $50(-0.791)$ & $94(0.774)$ & n.a. \\
\hline$\eta_{\mathrm{E}}$ & 241.7 & $62(-0.685)$ & $23.8(0.866)$ & $30(-0.817)$ & $150(0.79)$ & $235(-0.775)$ & $25(0.763)$ \\
\hline
\end{tabular}

* response models do not take into account physico-chemical limitations, and values above $100 \%$ were calculated.

n.a. $=$ not affected.

As can be seen, the space time, $\tau$, required to achieve this best individual performance for each response needs to be high, usually $235 \mathrm{~g}$ cat $\cdot h \cdot \mathrm{mol}_{\text {phenol }}{ }^{-1}$. In order to assure the maximum high degrees of oxidation in terms of phenol, oxygen demand and TOC, only wastewater with high ThOD feed 
$\left(>16.2 \mathrm{~g} \cdot \mathrm{L}^{-1}\right)$ could be suitably treated under high reaction temperatures $\left(100-130^{\circ} \mathrm{C}\right)$ and an excess of $\mathrm{H}_{2} \mathrm{O}_{2}$ dose. However, this scenario is far from that in which complete and efficient $\mathrm{H}_{2} \mathrm{O}_{2}$ consumption occurs and, consequently, far from being a cost-effective treatment $[2,36]$.

The wastewater with the maximum chemical oxygen demand selected $\left(\mathrm{ThOD}_{\text {feed }}=23.8 \mathrm{~g} \cdot \mathrm{L}^{-1}\right)$ and its treatment under an excess of $\mathrm{H}_{2} \mathrm{O}_{2}$ guarantee the production of energy upon CWPO $\left(\eta_{\mathrm{E}}>200 \%\right)$ while the reaction temperature can be set to $65^{\circ} \mathrm{C}$, and $\mathrm{T}_{\text {input }}$ and $\mathrm{T}_{\text {output }}$ to 25 and $30^{\circ} \mathrm{C}$, respectively (Table 4).

Considering the practical application of the treatment, the CWPO performance has been optimized in order to achieve the maximum oxidation degree, in terms of $\mathrm{X}_{\mathrm{ThOD}}$, with the most efficient consumption of $\mathrm{H}_{2} \mathrm{O}_{2}$ and most favorable energetic conditions. For that, a multi-objective optimization has been carried out using linear scalarization to find the optimal values for the operating conditions $\left(T_{R}, H P\right.$ excess, $\tau$ and $\left.T_{\text {output }}\right)$ for a given wastewater $\left(T_{\text {input }}\right.$ and $\left.T h O D_{\text {feed }}\right)$ that assure the greatest values of the selected objectives $\left(X_{T h O D}, \eta_{\mathrm{H}_{2} \mathrm{O}_{2}}\right.$ and $\left.\eta_{\mathrm{E}}\right)$ :

$$
y_{\text {opt }}(\%)=X_{T h O D}(\%)+\eta_{H_{2} \mathrm{O}_{2}}(\%)+\eta_{E}(\%)
$$

where $y_{\text {opt }}$ is the function that allows increasing the three responses $X_{T h O D}, \eta_{\mathrm{H}_{2} \mathrm{O}_{2}}$ and $\eta_{\mathrm{E}}$ with the same weight in Equation (7). The optimal operating conditions for $\mathrm{T}_{\mathrm{R}}, \mathrm{T}_{\text {output }}, \mathrm{HP}$ excess and $\tau$ in the 10 cases of multi-criteria optimization calculated by setting $\mathrm{T}_{\text {input }}=20{ }^{\circ} \mathrm{C}$ and $\mathrm{ThOD}_{\text {feed }}$ between 2.38-23.8 g. $\mathrm{L}^{-1}$ are summarized in Table 5. Besides, the values of the six response variables-i.e., $X_{\text {phenol }}, X_{\text {ThOD }}, X_{T O C}, X_{\mathrm{H}_{2} \mathrm{O}_{2}}, \eta_{\mathrm{H}_{2} \mathrm{O}_{2}}$ and $\eta_{\mathrm{E}}$ - estimated by simulation with Aspen Plus and by the response quadratic models (in brackets) are included.

Table 5. Optimal operating conditions and corresponding response values calculated by the Aspen Plus ${ }^{\circledR}$ v11 simulator as a function of the chemical oxygen demand flow rate fed to a CWPO unit to accomplish the multi-objective optimization of Equation (7). The values predicted by the quadratic models are in brackets.

\begin{tabular}{|c|c|c|c|c|c|c|c|c|c|c|c|}
\hline ThOD $_{\text {feed }}$ & $\mathbf{T}_{\mathrm{R}}$ & $\mathbf{T}_{\text {output }}$ & $\mathrm{HP}_{\text {excess }}$ & $\tau$ & $\mathbf{T}_{\text {input }}$ & $X_{\text {phenol }}$ & $\mathrm{X}_{\mathrm{ThOD}}$ & $\mathbf{X}_{\mathrm{TOC}}$ & $\mathrm{X}_{\mathrm{H}_{2} \mathrm{O}_{2}}$ & $\eta_{\mathrm{H}_{2} \mathrm{O}_{2}}$ & $\eta_{\mathrm{E}}$ \\
\hline$\left(\mathrm{g} \mathrm{L}^{-1}\right)$ & $\left({ }^{\circ} \mathrm{C}\right)$ & $\left({ }^{\circ} \mathrm{C}\right)$ & $(\%)$ & (g.h. $\mathrm{mol}$ & 1) $\left({ }^{\circ} \mathrm{C}\right)$ & $(\%)$ & $(\%)$ & $(\%)$ & $(\%)$ & $(\%)$ & $(\%)$ \\
\hline 2.38 & 129 & 30 & 59 & 235 & 20 & 66 [37] & 44 [12] & 41 [19] & $76[55]$ & 78 [69] & 95 [100] \\
\hline 4.76 & 123 & 32 & 73 & 235 & 20 & $91[60]$ & 67 [32] & 63 [36] & 93 [61] & 80 [73] & 113 [100] \\
\hline 7.14 & 118 & 38 & 88 & 235 & 20 & 99 [79] & $76[50]$ & $72[50]$ & $89[66]$ & 79 [76] & 131 [100] \\
\hline 9.52 & 113 & 46 & 100 & 235 & 20 & $100[92]$ & 78 [63] & 74 [62] & 83 [71] & 77 [78] & 146 [100] \\
\hline 11.9 & 110 & 55 & 100 & 235 & 20 & 100 [100] & 78 [71] & 74 [70] & 84 [78] & 76 [79] & 159 [100] \\
\hline 14.3 & 106 & 60 & 100 & 235 & 20 & $100[>100]$ & 78 [78] & 74 [75] & 85 [84] & 75 [79] & 177 [104] \\
\hline 16.7 & 103 & 60 & 100 & 235 & 20 & $100[>100]$ & $78[81]$ & $74[78]$ & 87 [87] & 74 [79] & 203 [115] \\
\hline 19.0 & 100 & 60 & 100 & 235 & 20 & $100[>100]$ & 78 [83] & $74[80]$ & 88 [88] & 72 [77] & 231 [127] \\
\hline 21.4 & 96 & 60 & 100 & 235 & 20 & 100 [99] & 78 [82] & 74 [79] & 89 [87] & $71[76]$ & 262 [140] \\
\hline 23.8 & 93 & 60 & 100 & 235 & 20 & $100[91]$ & 78 [79] & 74 [76] & $90[84]$ & $71[73]$ & 296 [154] \\
\hline
\end{tabular}

As can be seen, the highest oxidation performance for operation under energetically self-sustaining conditions $\left(\eta_{\mathrm{E}}>100 \%\right)$ corresponds to $\mathrm{X}_{\mathrm{phenol}}, \mathrm{X}_{\mathrm{ThOD}}$ and $\mathrm{X}_{\mathrm{TOC}}$ values of $100 \%, 78 \%$ and $74 \%$, respectively, and it is achieved from a ThOD feed of $9.52 \mathrm{~g} \cdot \mathrm{L}^{-1}$ and at the stoichiometric dose of $\mathrm{H}_{2} \mathrm{O}_{2}$. An increase in the organic load in the wastewater (from the 9.52 to $23.8 \mathrm{~g} \cdot \mathrm{L}^{-1}$ ) allows a decrease in the reaction temperature (from 123 to $93^{\circ} \mathrm{C}$ ) and an increase in the heat release. These conditions of COD content and temperature are in between those accepted for the AOPs at near ambient conditions and for other thermal wet oxidation technologies such as the well established CWAO [1]. Note that the 10 cases studied (Table 5) comprise the most cost-effective options for the CWPO operation. Taking into account that the operational cost is mainly due to the $\mathrm{H}_{2} \mathrm{O}_{2}$ consumption, since the contribution of the catalyst can be considered negligible in continuous operation, a cost between 0.70 and $11.60 € \mathrm{~m}^{-3}$ of treated wastewater has been estimated for $\mathrm{ThOD}_{\text {feed }}$ between 2.38 and $23.8 \mathrm{~g} \mathrm{~L}^{-1}$, respectively. For the calculations, the excess of $\mathrm{H}_{2} \mathrm{O}_{2}$ has been considered, with a cost of $\mathrm{H}_{2} \mathrm{O}_{2}$ equal to $0.23 € \mathrm{~L}^{-1}$ [52]. 
According to the above results, the CWPO process should be considered as a treatment able to abate recalcitrant compounds such as phenol and to increase the detoxification of the wastewater (due to the oxidation of recalcitrant compounds into organic acids) before its disposal via a biological process. The CWPO process could be successful in treating a wide range of industrial wastewaters as a one-step treatment and then oriented to increase the quality of the treated effluent for water reuse or safe discharge.

\section{Conclusions}

It has been demonstrated that CWPO aims to fill the gap between the AOPs under near ambient conditions and CWAO processes. The advantages of CWPO include the treatment of mildly loaded wastewater, with a COD demand between 9.5 and $24 \mathrm{~g} \mathrm{~L}^{-1}$, under mild operating conditions $\left(\mathrm{T}_{\mathrm{R}}=\right.$ 93-130 ${ }^{\circ} \mathrm{C}, \mathrm{P}=1-4 \mathrm{~atm}$ and a stoichiometric dose of $\mathrm{H}_{2} \mathrm{O}_{2}$ ) in an autothermal fixed bed reactor. In addition, there is the possibility of energy recovery, to a greater or lesser extent depending on the inlet $\mathrm{COD}$ and the reaction temperature.

This study demonstrates that:

- The COD removal achieved in CWPO units is increased by increasing the reaction temperature and dose of hydrogen peroxide. Nevertheless, the best conditions lead to $78 \%$ COD conversion due to the refractoriness of the organic acid species.

- Working at high temperature favors the efficient consumption of $\mathrm{H}_{2} \mathrm{O}_{2}$ in the oxidation process.

- Autothermal operation is possible if a high load of COD (or TOC) is employed and high conversions are achieved, which requires setting up the process with the optimal operating conditions.

Clearly, the CWPO process is a promising technology for reducing the impact of non-biodegradable hazardous substances on the environment.

Supplementary Materials: The following are available online at http://www.mdpi.com/2073-4344/10/5/548/s1, Figure S1: Influence of the operating variables (A-F) and conversions (G-I) on the energetic efficiency of the CWPO process, Table S1: Elementary reactions considered in the CWPO reactor according to the oxidation pathway and kinetic model reported in Diaz de Tuesta et al. (2017), Table S2: Binary coefficients (aij, aji, bij, bji) estimated for the implementation of the UNIQUAC thermodynamic model in the simulator software, Table S3: Theoretical oxygen demand (ThOD) and total organic carbon (TOC) of each compound (i).

Author Contributions: Conceptualization, J.A.C. and A.Q.; Funding acquisition, J.A.C.; Investigation, J.L.D.d.T.; Methodology, J.L.D.d.T. and A.Q.; Software, J.L.D.d.T., D.M. and V.R.F.; Supervision, V.R.F. and J.A.C.; Validation, D.M.; Writing—original draft, J.L.D.d.T.and A.Q.; Writing—review \& editing, V.R.F. and J.A.C. All authors have read and agree to the published version of the manuscript.

Funding: This research received no external funding.

Acknowledgments: The authors thank the financial support by the Spanish Government and Comunidad de Madrid through the projects CTM2016-76454-R and S2018/EMT-4341, respectively. Also, the authors acknowledge financial support to the Portugal Government through the project UIDB/00690/2020.

Conflicts of Interest: The authors declare no conflict of interest.

\section{References}

1. Andreozzi, R.; Caprio, V.; Insola, A.; Marotta, R. Advanced oxidation processes (AOP) for water purification and recovery. Catal. Today 1999, 53, 51-59. [CrossRef]

2. De Heredia, J.B.; Domínguez, J.R.; Peres, J.A. Eliminación de compuestos fenólicos por oxidación avanzada: Estimación de costes. Ing. Química 2002, 386, 142-146.

3. Esplugas, S.; Gimenez, J.; Contreras, S.; Pascual, E.; Rodriguez, M. Comparison of different advanced oxidation processes for phenol degradation. Water Res. 2002, 36, 1034-1042. [CrossRef]

4. Perathoner, S.; Centi, G. Wet hydrogen peroxide catalytic oxidation (WHPCO) of organic waste in agro-food and industrial streams. Top. Catal. 2005, 33, 207-224. [CrossRef]

5. Fajerwerg, K.; Debellefontaine, H. Wet oxidation of phenol by hydrogen peroxide using heterogeneous catalysis Fe-ZSM-5: A promising catalyst. Appl. Catal. B Environ. 1996, 10, L229. [CrossRef] 
6. Debellefontaine, H.; Chakchouka, M.; Foussarda, J.N.; Tissot, D.; Striolo, P. Treatment of organic aqueous wastes: Wet air oxidation and wet peroxide oxidation ${ }^{\circledR}$. Environ. Pollut. 1996, 92, 155-164. [CrossRef]

7. Catrinescu, C.; Teodosiu, C.; Macoveanu, M.; Miehe-Brendle, J.; Le Dred, R. Catalytic wet peroxide oxidation of phenol over Fe-exchanged pillared beidellite. Water Res. 2003, 37, 1154-1160. [CrossRef]

8. Lücking, F.; Köser, H.; Jank, M.; Ritter, A. Iron powder, graphite and activated carbon as catalysts for the oxidation of 4-chlorophenol with hydrogen peroxide in aqueous solution. Water Res. 1998, 32, 2607-2614. [CrossRef]

9. Pignatello, J.J.; Oliveros, E.; Mac Kay, A. Advanced Oxidation Processes for Organic Contaminant Destruction Based on the Fenton Reaction and Related Chemistry. Crit. Rev. Environ. Sci. Technol. 2006, 36, 1-84. [CrossRef]

10. Rey, A.; Faraldos, M.; Bahamonde, A.; Casas, J.A.; Zazo, J.A.; Rodriguez, J.J. Role of the Activated Carbon Surface on Catalytic Wet Peroxide Oxidation. Ind. Eng. Chem. Res. 2008, 47, 8166-8174. [CrossRef]

11. Navalon, S.; Dhakshinamoorthy, A.; Alvaro, M.; Garcia, H. Heterogeneous Fenton catalysts based on activated carbon and related materials. ChemSusChem 2011, 4, 1712-1730. [CrossRef] [PubMed]

12. Dhakshinamoorthy, A.; Navalon, S.; Alvaro, M.; Garcia, H. Metal Nanoparticles as Heterogeneous Fenton Catalysts. ChemSusChem 2012, 5, 46-64. [CrossRef] [PubMed]

13. Munoz, M.; de Pedro, Z.; Casas, J.A.; Rodriguez, J.J. Preparation of magnetite-based catalysts and their application in heterogeneous Fenton oxidation-A review. Appl. Catal. B Environ. 2015, 176, 249-265. [CrossRef]

14. Guo, J.; Al-Dahhan, M. Catalytic Wet Oxidation of Phenol by Hydrogen Peroxide over Pillared Clay Catalyst. Ind. Eng. Chem. Res. 2003, 42, 2450-2460. [CrossRef]

15. Martínez, F.; Melero, J.A.; Botas, J.A.; Pariente, I.; Molina, R. Treatment of Phenolic Effluents by Catalytic Wet Hydrogen Peroxide Oxidation over $\mathrm{Fe}_{2} \mathrm{O}_{3} / \mathrm{SBA}-15$ Extruded Catalyst in a Fixed-Bed Reactor. Ind. Eng. Chem. Res. 2007, 46, 4396-4405. [CrossRef]

16. Martínez, F.; Pariente, I.; Melero, J.A.; Botas, J.A.; Gómez, E. Catalytic wet peroxidation of phenol in a fixed bed reactor. Water Sci. Technol. 2007, 55, 75-81. [CrossRef]

17. Botas, J.A.; Melero, J.A.; Martinez, F.; Pariente, M.I. Assessment of $\mathrm{Fe}_{2} \mathrm{O}_{3} / \mathrm{SiO}_{2}$ catalysts for the continuous treatment of phenol aqueous solutions in a fixed bed reactor. Catal. Today 2010, 149, 334-340. [CrossRef]

18. Ferentz, M.; Landau, M.V.; Vidruk, R.; Herskowitz, M. Fixed-bed catalytic wet peroxide oxidation of phenol with titania and Au/titania catalysts in dark. Catal. Today 2015, 241, 63-72. [CrossRef]

19. Yan, Y.; Wu, X.; Zhang, H. Catalytic wet peroxide oxidation of phenol over $\mathrm{Fe}_{2} \mathrm{O}_{3} / \mathrm{MCM}-41$ in a fixed bed reactor. Sep. Purif. Technol. 2016, 171, 52-61. [CrossRef]

20. Martínez, F.; Pariente, I.; Melero, J.A.; Botas, J.A. Catalytic Wet Peroxide Oxidation Process for the Continuous Treatment of Polluted Effluents on a Pilot Plant Scale. J. Adv. Oxid. Technol. 2016, 11, 65-74. [CrossRef]

21. Taran, O.P.; Zagoruiko, A.N.; Ayusheev, A.B.; Yashnik, S.A.; Prihod'ko, R.V.; Ismagilov, Z.R.; Goncharuk, V.V.; Parmon, V.N. Wet peroxide oxidation of phenol over Cu-ZSM-5 catalyst in a flow reactor. Kinetics and diffusion study. Chem. Eng. J. 2015, 282, 108-115. [CrossRef]

22. Quintanilla, A.; Casas, J.A.; Miranzo, P.; Osendi, M.I.; Belmonte, M. 3D-Printed Fe-doped silicon carbide monolithic catalysts for wet peroxide oxidation processes. Appl. Catal. B Environ. 2018, 235, 246-255. [CrossRef]

23. Quintanilla, A.; Carbajo, J.; Casas, J.A.; Miranzo, P.; Osendi, M.I.; Belmonte, M. Graphene-based nanostructures as catalysts for wet peroxide oxidation treatments: From nanopowders to 3D printed porous monoliths. Catal. Today 2019. [CrossRef]

24. Ou, X.; Pilitsis, F.; Xu, N.; Taylor, S.F.R.; Warren, J.; Garforth, A.; Zhang, J.; Hardacre, C.; Jiao, Y.; Fan, X.; et al. On developing ferrisilicate catalysts supported on silicon carbide ( $\mathrm{SiC}$ ) foam catalysts for continuous catalytic wet peroxide oxidation (CWPO) reactions. Catal. Today 2018. [CrossRef]

25. Ou, X.; Pilitsis, F.; Jiao, Y.; Zhang, Y.; Xu, S.; Jennings, M.; Yang, Y.; Taylor, S.F.R.; Garforth, A.H.; Hardacre, C.; et al. Hierarchical Fe-ZSM-5/SiC foam catalyst as the foam bed catalytic reactor (FBCR) for catalytic wet peroxide oxidation (CWPO). Chem. Eng. J. 2019, 362, 53-62. [CrossRef]

26. Peralta, Y.M.; Sanabria, N.R.; Carriazo, J.G.; Moreno, S.; Molina, R. Catalytic wet hydrogen peroxide oxidation of phenolic compounds in coffee wastewater using Al-Fe-pillared clay extrudates. Desalin. Water Treat. 2015, 55, 647-654. [CrossRef] 
27. Caudo, S.; Centi, G.; Genovese, C.; Perathoner, S. Copper- and iron-pillared clay catalysts for the WHPCO of model and real wastewater streams from olive milling production. Appl. Catal. B Environ. 2007, 70, 437-446. [CrossRef]

28. Azabou, S.; Najjar, W.; Bouaziz, M.; Ghorbel, A.; Sayadi, S. A compact process for the treatment of olive mill wastewater by combining wet hydrogen peroxide catalytic oxidation and biological techniques. J. Hazard. Mater. 2010, 183, 62-69. [CrossRef]

29. Maduna Valkaj, K.; Kaselj, I.; Smolkovic, J.; Zrnčević, S.; Kumar, N.; Murzin, D.Y. Catalytic wet peroxide oxidation of olive oil mill wastewater over zeolite based catalyst. Chem. Eng. Trans. 2015, 43, 853-858.

30. Dominguez, C.M.; Quintanilla, A.; Casas, J.A.; Rodriguez, J.J. Treatment of real winery wastewater by wet oxidation at mild temperature. Sep. Purif. Technol. 2014, 129, 121-128. [CrossRef]

31. Torres-Luna, J.A.; Giraldo-Gomez, G.I.; Sanabria-Gonzalez, N.R.; Carriazo, J.G. Catalytic degradation of real-textile azo-dyes in aqueous solutions by using $\mathrm{Cu}-\mathrm{Co} /$ halloysite. Bull. Mater. Sci. 2019, 42, 1-10. [CrossRef]

32. Melero, J.A.; Martinez, F.; Botas, J.A.; Molina, R.; Pariente, M.I. Heterogeneous catalytic wet peroxide oxidation systems for the treatment of an industrial pharmaceutical wastewater. Water Res. 2009, 43, 4010-4018. [CrossRef]

33. Bautista, P.; Mohedano, A.F.; Casas, J.A.; Zazo, J.A.; Rodriguez, J.J. Oxidation of cosmetic wastewaters with $\mathrm{H}_{2} \mathrm{O}_{2}$ using a Fe/gamma- $\mathrm{Al}_{2} \mathrm{O}_{3}$ catalyst. Water Sci. Technol. 2010, 61, 1631-1636. [CrossRef]

34. Díaz de Tuesta, J.L.; García-Figueruelo, C.; Quintanilla, A.; Casas, J.A.; Rodriguez, J.J. Application of high-temperature Fenton oxidation for the treatment of sulfonation plant wastewater. J. Chem. Technol. Biotechnol. 2015, 90, 1839-1846. [CrossRef]

35. Pariente, M.; Melero, J.A.; Martinez, F.; Botas, J.A.; Gallego, A.I. Catalytic wet hydrogen peroxide oxidation of a petrochemical wastewater. Water Sci. Technol. 2010, 61, 1829-1836. [CrossRef] [PubMed]

36. Rueda, J.J.; Levchuk, I.; Sillanpää, M. Application of CatalyticWet Peroxide Oxidation for Industrial and Urban Wastewater Treatment: A Review. Catalysts 2018, 8, 673. [CrossRef]

37. Velichkova, F.; Julcour-Lebigue, C.; Koumanova, B.; Delmas, H. Heterogeneous Fenton oxidation of paracetamol using iron oxide (nano) particles. J. Environ. Chem. Eng. 2013, 1, 214-1222. [CrossRef]

38. Silva, A.S.; Kalmakhanova, M.; Massalimova, B.; Juliana, G.S.; De Tuesta, J.L.D.; Gomes, H.; Sgorlon, J.G.; De Tuesta, J.L.D.; De Tuesta, J.D.; Gomes, H. Wet Peroxide Oxidation of Paracetamol Using Acid Activated and Fe/Co-Pillared Clay Catalysts Prepared from Natural Clays. Catalysts 2019, 9, 705. [CrossRef]

39. Munoz, M.; Conde, J.; de Pedro, Z.M.; Casas, J.A. Antibiotics abatement in synthetic and real aqueous matrices by $\mathrm{H}_{2} \mathrm{O}_{2} /$ natural magnetite. Catal. Today 2018, 313, 142-147. [CrossRef]

40. Diaz de Tuesta, J.L.; Quintanilla, A.; Casas, J.A.; Rodriguez, J.J. Kinetic modeling of wet peroxide oxidation with a carbon black catalyst. Appl. Catal. B Environ. 2017, 209, 701-710. [CrossRef]

41. Dobrijevic, M.; Claeys-Bruno, M.; Sergent, M.; Phan-Tan-Luu, R. Experimental designs for the determination of key reactions in photochemical models: Application to the photochemistry of hydrocarbons in the atmosphere of Titan. Planet. Space Sci. 2008, 56, 519-529. [CrossRef]

42. Karimi, M.C.; Silva, J.A.; Gonçalves, C.N.; Diaz de Tuesta, J.L.; Rodrigues, A.E.; Gomes, H.T. CO $\mathrm{CO}_{2}$ Capture in Chemically and Thermally Modified Activated Carbons Using Breakthrough Measurements: Experimental and Modeling Study. Ind. Eng. Chem. Res. 2018, 57, 11154-11166. [CrossRef]

43. Lefèvre, S.; Ferrasse, J.H.; Boutin, O.; Sergent, M.; Faucherand, R.; Viand, A. Process optimisation using the combination of simulation and experimental design approach: Application to wet air oxidation. Chem. Eng. Res. Des. 2011, 89, 1045-1055. [CrossRef]

44. Lefèvre, S.; Ferrasse, J.H.; Faucherand, R.; Viand, A.; Boutin, O. Energetic optimization of wet air oxidation process using experimental design coupled with process simulation. Energy 2012, 41, 175-183. [CrossRef]

45. Constantine, M.T.; Cain, E.F. Chemical and Material Sciences Department, Research Division Rocketdyne. In Hydrogen Peroxide Handbook; Division of North American Aviation, Inc.: Canoga Park, CA, USA, 1967.

46. Giguère, P.A. The thermal decomposition of hydrogen peroxide vapour. II. Can. J. Res. 1947, 25b, 135-150. [CrossRef]

47. Giguère, P.A.; Liu, I.D. Kinetics of the thermal decomposition of hydrogen peroxide vapor. Can. J. Chem. 1957, 35, 283-293. [CrossRef]

48. Scatchard, G.; Kavanagh, G.M.; Ticknor, L.B. Vapor-Liquid Equilibrium. VIII. Hydrogen Peroxide-Water Mixtures1. J. Am. Chem. Soc. 1952, 74, 3715-3720. [CrossRef] 
49. Wichterle, I.; Linek, J.; Wagner, Z.; Fontaine, J.C.; Sosnkowska-Kehiaian, K.; Kehiaian, H.V. Vapor-Liquid Equilibrium of the Mixture $\mathrm{H}_{2} \mathrm{O}+\mathrm{H}_{2} \mathrm{O}_{2}$. In Binary Liquid Systems of Nonelectrolytes. Part 2; Kehiaian, H.V., Ed.; Springer Materials: Berlin, Germany, 2008; Volume 13A2.

50. Diaz de Tuesta, J.L.; Quintanilla, A.; Casas, J.A.; Rodriguez, J.J. P-, B- and N-doped carbon black for the catalytic wet peroxide oxidation of phenol: Activity, stability and kinetic studies. Catal. Commun. 2017, 102, 131-135. [CrossRef]

51. Lavric, E.D.; Weyten, H.; De Ruyck, J.; Pleşu, V.; Lavric, V. Delocalized organic pollutant destruction through a self-sustaining supercritical water oxidation process. Energy Convers. Manag. 2005, 46, 1345-1364. [CrossRef]

52. Zazo, J.A.; Pliego, G.; Blasco, S.; Casas, J.A.; Rodriguez, J.J. Intensification of the Fenton Process by Increasing the Temperature. Ind. Eng. Chem. Res. 2011, 50, 866-870. [CrossRef]

(C) 2020 by the authors. Licensee MDPI, Basel, Switzerland. This article is an open access article distributed under the terms and conditions of the Creative Commons Attribution (CC BY) license (http://creativecommons.org/licenses/by/4.0/). 